\title{
Üniversite Öğrencilerinin Kişilik Tipleri İle Girişimcilik Eğilimleri Arasındaki İlişkinin Demografik Özellikler Açısından İncelenmesi: Bir Vakıf Üniversitesi Örneği
}

DOI: $10.26466 /$ opus.944182

\begin{abstract}
Vildan Bayram * - Mesut Öztırak ${ }^{* *}$
* Doktora Öğrencisi., İstanbul Aydın Üniversitesi, Lisansüstü Eğitim Enstitüsü, İstanbul/Türkiye E-Posta: vildanbayram@stu.aydin.edu.tr

ORCID: $\underline{0000-0001-7526-6485}$

** Öğr. Gör.,İstanbul Esenyurt Üniversitesi, MYO,Sivil Hava Ulaştırma İşl. Prog.İstanbul/Türkiye E- Posta: mesutoztirak@esenyurt.edu.tr

ORCID: $\underline{0000-0003-4828-7293}$

Öz
\end{abstract}

Bu çalışmanın temel amacı, üniversite öğrencilerinin kişilik tipleri ile girişimcilik eğilimleri arasındaki ilişkide demografik özelliklerin etkisini araştırmaktır. Bu amaç doğrultusunda öğrencilerin kişilik özellikleri ve girişimcilik eğilimleri incelenmiş, demografik özelliklerin girişimcilik eğilimlerine etkisi araştırılmıştır. Çalışma ile ilgili olarak İstanbul Esenyurt Üniversitesi'nden 20.05.2021 tarihli ve 2021/06-09 No'lu gerekli etik kurul izni alınmıştır. Bu amaçla kolayda örneklem yöntemi kullanlarak, bir vakıf üniversitesinde öğrenim gören 196 öğrenciye ulaşılmıştır. Toplanan veriler SPSS 21.0 programı ile analiz edilmiştir. Analizlerde parametrik olan Bağımsız gruplar t testi, ANOVA testi, Tukey testi ve Pearson korelasyon testi kullanılmıştır. Kişilik özellikleri beş faktör altında incelenmişstir. Araştırma sonuçlarnna göre farklı kişilik tiplerinin girişimcilik eğilimlerinin de farklı olduğu ortaya çıkmıştır. Dışa dönük kişiliğge sahip öğrencilerin girişimcilik eğilimlerinin daha yüksek olduğunu, girişimcilik eğitimi almış öğrencilerin ve ailesinde girişimci olan öğrencilerin girişim eğilimlerinin arttığı ifade edilebilir. Üniversite öğrencilerinin kişilik tipleri dikkate alınarak, girişimcilik eğilimleri geliştirildiği taktirde iş hayatında daha etkili olacağı ve kendi işlerini kurmak yönünde daha kararl davranacakları düşünülmektedir. Üniversite eğitimleri sırasında aldiklar girişimcilik eğitimleri sayesinde kurduklarn firmalarda başarıyı yakalayacak, firmalarn sürdürülebilirliğini sağlayarak ekonomiye katkıda bulunacaklardır. Çalışma, hem öğrencilerin kişilik özelliklerine göre girişimcilik eğilimlerinin geliştirilmesine ışık tutmak, hem de demografik özelliklerin girişimcilik eğilimleri üzerindeki etkisine dikkat çekmek için yol gösterici olarak önem arz etmektedir.

Anahtar Kelimeler: Girişimci, Girişimcilik, Girişimcilik Ĕ̆gilimi, Kişilik Tipleri, Demografik Özellikler. 


\title{
Examining the Relationship between University Students' Personality Types and Entrepreneurial Tendencies in Terms of Demographic Characteristics: An Example of a Foundation University
}

\begin{abstract}
The main purpose of this study is to investigate the effect of demographic characteristics on the relationship between university students' personality types and entrepreneurial tendencies. For this purpose, students' personality traits and entrepreneurship tendencies were examined, and the effects of demographic characteristics on entrepreneurial tendencies were investigated. For this aim, 196 students studying at a foundation university were reached using the convenience sampling method. Collected data were analyzed with SPSS 21.0 program. Independent groups $t$ test, ANOVA test, Tukey test and Pearson correlation test were used in the analyzes. Personality traits were examined under five factors. According to the results of the research, it has been revealed that different personality types have different entrepreneurial tendencies. It can be stated that the entrepreneurial tendencies of students with extroverted personality are higher, the entrepreneurship tendencies of students who have received entrepreneurship education and those who have entrepreneurs in their families increase. Considering the personality types of university students, if their entrepreneurship tendencies are developed, they will be more effective in business life and will be more determined to establish their own businesses. Thanks to the entrepreneurship training they received during their university education, they will achieve success in the companies they have established and contribute to the economy by ensuring the sustainability of the companies. The study is important as a guide both to shed light on the development of entrepreneurship tendencies according to students' personality traits and to draw attention to the effect of demographic characteristics on entrepreneurial tendencies.
\end{abstract}

Key Words: Entrepreneur, Entrepreneurship, Entrepreneurship Tendency, Personality Types, Demographic Features. 


\section{Giriş}

Girişimcilik Türkiye' de ve dünyada ekonomiyi ileriye götüren bir motor güç haline gelmiştir. Küreselleşen dünyada, hızla değişen ekonomik koşullar nedeniyle yeni girişimlerin yapılması ve yeni girişimcilerin yetişmesi beklenmektedir. Yeni girişimler, inovatif fikirlerle mevcut kaynakları en verimli şekilde kullanarak ekonominin gelişmesine katkıda bulunmaktadır. Girişimcilik yoluyla bireysel kazanç sağlamanın yanı sıra topluma ve ülke ekonomisine ortak bir fayda yaratılmaktadır. Bunun yanı sıra istihdam oluşturulmakta ve sosyal refah yükseltilmektedir.

Girişimcilik, her dönemde ülkelerin ekonomik temelini oluşturan büyük bir güçtür. Bu gücü doğru yönlendirmek ve girişimlerin kurumsallaşarak sürdürülebilirliğini sağlamak, ekonomik dinamiklerin düzenli işlemesi için gerekli unsurlardan biridir.

Literatür incelendiğinde, bireylerin girişimcilik eğilimi üzerinde kişisel özelliklerin önemli bir etkisi olduğu görülmüştür (Davidsson, 1995; Zhao vd., 2010; Zain vd., 2010, Ulucan, 2015). Bu araştırmada, geleceğin girişimcileri olan üniversite öğrencilerinin kişilik tipleri ile girişimcilik eğilimleri arasındaki ilişkide demografik özelliklerin ve girişimcilik eğitiminin etkisi araştırılmıştır. Bu amaçla bir vakıf üniversitesinde okuyan üniversite öğrencilerine ulaşılarak onların kişilik özellikleri incelenmiş, aldıkları girişimcilik derslerinin girişimcilik eğilimlerine ne derece etkisi olduğu, ailelerinde bulunan girişimcilerden ne derece etkilendikleri araştırılmıştır. Çalışmada ayrıca katılımcı öğrencilerin demografik özellikleri ile girişimcilik eğilimleri arasında anlamlı bir ilişki olup olmadığ 1 da araştırılmıştır.

Çalışmanın bazı kısıtlar içermektedir. Verilerin toplandığı tarih Covid 19 salgınının yaşandığı döneme denk gelmiştir. Bu dönemde üniversite öğrencileri online eğitim görmektedir. Salgın psikolojisi ve yüzyüze eğitimin olmaması, öğrencilerin anket soruların yantlarken özgürce değerlendirme yapmalarına imkan vermemiş olabilir. Bunun yanı sıra veriler yalnızca bir vakıf üniversitesinde eğitim gören öğrencilerden toplanmıştır. Dolayısıyla sonuçlar genelleştirilememektedir. Örneklem grubunun daha geniş tutulduğu çalışmalar daha sağlıklı sonuçlara ulaşma imkânı sağlayacaktır. İleride yapılacak çalışmalarda devlet üniversiteleri ve vakıf 
üniversitelerinde verilen girişimcilik dersinin öğrencilerin girişimcilik eğilimini ne yönde etkilediği karşılaştırılabilir.

\section{Kişilik Tipleri}

Kişilik, bireylerin kendine özgü karakter, düşünce ve davranışını belirleyen psikofiziksel sistemlerin dinamik örgütlenmesidir (Allport, 1961, s.28). Kişilik, bireyi farklı kılan bedensel, zihinsel, ruhsal tutum ve davranışların tümüdür (Richards ve Schmidt, 2002, s.394; George ve Jones, 2012, s.38; Tutar, 2012, s.43; Dal ve Eroğlu, 2015, s.362; Divanoğlu ve Uslu, 2018, s.4341). Buna ilaveten bireyin duyuş, düşünüş ve davranış şekillerini etkileyen dinamik ve özdüzenleyici sistemlerin birleşiminin kişiye özgü yansımasıdır (Kılıç ve Bozkaya, 2014, s.154; Alan ve Korkmaz, 2017, s.109; Uğur ve Okutan, 2018, s.6; Tokmak, 2018, s.2221). Kişilik doğuştan var olan ve sonradan edinilen eğilimlerin bütününden meydana gelmiştir (Eren, 2008, s.83; Güney, 2017, s.15). Bu nedenle kişilik bireyden bireye değişiklik göstermektedir.

Kişilik tipleri, Beş Faktör Kişilik Kuramında bulunan özellik yaklaşımına dayanmaktadır. Kişiyi tanımlamak için kullanılan özellikleri beş faktör altında sınıflandırmıştır ve Ayırıcı Özellikler Kuramı bünyesinde yer almaktadır (Baltacı, 2017, s.60; Kılıçlar vd., 2017, s.96; Polatçı vd., 2017, s.557). Literatür incelendiğinde kişilik tiplerini sınıflandırmaya çalışan araştırmacıların "Beş Faktör Kişilik Modeli" üzerinde genel bir uzlaşmaya vardığı anlaşılmaktadır (Goldberg, 1990, s.1217; Taggar vd., 1999, s.902; Deniz ve Erciş, 2010, s.143; Bal, 2018, s.75; Konakay ve Çelik, 2018, s.699). Beş Faktör Kişilik Kuramı, insanın kişilik yapısını ifade edecek bir sinıflamanın olabileceği temel varsayımına dayanmaktadır (Madran ve Akdoğan, 2010, s.368; İyem ve Erol, 2013, s.140; Tatlılığlu, 2014, s.943; Horzum vd., 2017, s.399). Kişilik tiplerini beş faktör altında toplamıştır.

Beş faktör kişilik ölçeği, kişilik yapılarını bütünleştirmesi, kişilik özellikleriyle davranışlar arasındaki korelasyonu incelemesi ve kişiliği beş alt faktörle sınırlandırması sebebiyle tercih edilmektedir (Tutar, 2016, s.63). Beş faktör kişilik kuramı kişiliği, dışadönüklük, uyumluluk, sorumluluk, nevrotiklik ve deneyime açiklık olmak üzere beş temel boyutta incelemektedir (Demirci vd., 2007, s.21; Ulu vd., 2016, s.169; Keleş ve 
Keleş, 2017, s.419; Güney, 2017, s.16). Bu beş boyutun ayırtedici özellikleri şu şekilde sıralanabilir (Burger, 2006):

- Dışadönüklük: Kendine güvenen, sosyal, karşılaştıkları durumları daha az riskli gören, sıcakkanlı, girişken, enerjisi yüksek ve daha iyimser bireylerdir.

- Uyumluluk: Fedakâr, sevecen, güvenilir, sosyal ilişkileri daha kuvvetli, daha az kavga eden ve iş birliği içinde çalışmayı isteyen bir yapıya sahiptir.

- Sorumluluk: Kendini kontrol edebilen, özdisiplin sahibi ve dikkatlidirler.

- Nevrotiklik: Öfke, kaygı, üzüntü ve suçluluk gibi olumsuz duygulardan herhangi birine yatkın olabilirler. Bu özellikleri nedeni ile diğer olumsuz duygulara da daha yatkın olduğu söylenebilir. Duygularında değişim olduğu için tedirgin edici durumlarla karşı karşıya kaldıklarında bulundukları ortamı terk etme eğilimine sahiptirler.

- Deneyime açıklık. Yenilik ve çeşitliliğe meraklı, değişime açık ve esnek, hayal gücü yüksek, çok yönlü düşünebilen ve geleneksel olarak hareket etmeyen bireylerdir.

Bugüne kadar yapılmış kişilik tipleri ile ilgili çalışmalar incelendiğinde kişiliğin beş faktörünün birçok çalışmada doğrulandığı ve kişilik farklılıklarını ölçtüğü görülmüştür (Riemann vd., 1997, s.450; Guenole ve Chernyshenko, 2005, s.86; Bacanlı vd., 2009, s.262; Erkuş ve Tabak, 2009, s.217; Basım vd., 2009, s.24; Çivitci ve Arıcıŏ̆lu, 2012, s.82; Tutar ve Yılmazer, 2012, s.19; Çetin vd., 2015, s.83; Karabatak, 2019, s.3).

\section{Girişimcilik Eğilimi}

Girişimci, emek, sermaye, teknoloji, yöntem ve doğal kaynakları bir araya getirerek insan ihtiyaçlarını karşılamak ve bu doğrultuda kazanç elde etmek amaciyla mal veya hizmet üretiminde bulunan ve riski göze alan gerçek veya tüzel kişi/kişiliktir (Atasoy, 2012, s.35; Şimşek ve Çelik, 2015; Kılınç ve Kanayıran, 2020, s.38). Girişimci kişiler, yaratıcılık özellikleri taşıyan, proaktif davranabilen ve risk alabilen kişilerdir (Runyan vd., 2008, s.569). Bu özellikleri sayesinde risk alarak girişim yapma davranış1 geliştirebilmektedirler. 
Girişimcilik fırsatları erken görebilme, gerekli riskleri almaktan çekinmeme ve eyleme geçmek için cesaret etme davranışları ile ilgili bir süreçtir (Ercan ve Gökdeniz, 2009, s.67; Özbey vd., 2016, s.2700). Girişimcilik, risk üstlenme, başlatma, yenilik, fırsatların peşinde koşma, strateji oluşturma, üretme gibi sözcüklerle tanımlanabilir. Girişimcilik kavramının devamlı olarak değişen bir değere sahip olduğu söylenebilir (Akçakanat vd., 2014, s.139; Gast ve Gundolf, 2017, s.46; Bozkurt vd., 2018, s.45).

Girişimciliği etkileyen, içsel ve dişsal birçok faktör bulunmaktadır. Araştırmalar sonucu girişimciliği etkileyen üç temel faktör belirlenmiştir (Bridge ve O'Neill, 2012, s.223; Öztırak, 2017):

- Geçmişten gelen faktörler: Genetik yapı, eğitim, aile, geçmişte kazanılan deneyimler gibi kişiye has özelliklerdir.

- Örgüt yapısıyla ilgili faktörler: İnsani ilişkiler, işle ilgili kazanılan bilgi ve beceri, iş tecrübesi, güdülenme ve coğrafi konum gibi örgüte ait değişkenlerdir.

- Çevresel faktörler: Kişisel ve işletmeye ait özelliklerin dışında kalan ekonomik şartlar, risk sermayesine ulaşılabilirlik, model girişimcilerin varlığı, danışmanlık hizmetlerinin olup olmaması, tüketici ve iş gücü yapısı, lojistik ve diğer hizmet desteklerine ulaşabilme gibi ekonomik ve sosyal öğelerdir.

Girişimcilik eğilimi, bireylerin girişimci olup olmama konusundaki istekliliklerini belirtmektedir. Bireyin kişisel beklentileri, deneyimleri ile toplumdaki sosyal normlar girişimcilik davranışını etkilemektedir (Polatcı ve Yeloğlu. 2021, s.78). Kişilere istihdam yaratma, piyasalara yeni ürün ve hizmet sunma ve ülke ekonomileri yeni bir soluk getirme noktasinda girişimcilere önemli roller düşmektedir (Akyüz, 2013, s.81). Girişimcilik eğilimi, kişinin girişimci olmaya dair inancını göstermektedir. Kişinin geleceğe dair vizyonu, fırsatları tanımlayıp değerlendirebileceğine dair inancı girişimcilik eğiliminde önemli bir rol oynamaktadır (Akkuş vd., 2018, s.172). Girişimcilik eğilimi ne kadar yüksek ise bireylerin girişimde bulunma davranışları da o kadar yüksek olacaktır.

Girişimcilik eğilimini geliştirmek için yararlanılan Ajzen ve Fishbein (1977)' in ortaya koymuş oldukları "Planlanmış Davranış Teorisi" bir eğitim modeli olarak kullanılmaktadır. Bu model, davranışa yönelik tutum, 
kişisel norm ve varsayılan davranış kontrolü olarak üç unsurdan oluşmaktadır (Top 2006, s.233):

- Davranışa yönelik tutum: Tutumsal inançlar sonucu, bir davranışı gösterecek olan kişinin, bu davranışı pozitif veya negatif olarak değerlendirmesi olarak açıklanmaktadır. Davranışa yönelik tutumlar; zengin olma, meydan okuma, kendini ispatlama ve kendine güvene yöneliktir. Birey ilerideki iş yaşamında yüksek gelir elde etmek için girişimci olmak isteyebilmektedir (Top, 2006, s.233-234). İşletme kurma eğilimi, girişimcilik hakkındaki tutumla oluşmaktadır (Erten, 2002, s.68). Tutum araçları, büyük oranda davranışların değişmesine sebep olmaktadır.

- Kişisel Norm: Diğer insanların normatif beklentileri hakkındaki inançlarıdır. Normatif inançların oluşturduğu davranışı yapacak olan kişi için önemli olan referans kişilerin, kurum veya kuruluşların belirli bir davranışın gerçekleşmesinin ya da terk edilmesinin beklentisi içinde olduklarını ifade etmektedir (Erten 2002, s.68). Kişisel norm girişimciliğin toplumda kabul görmesi ile ilgili bir unsurdur (Leroy vd. 2009, s.3). Girişimcilik eğilimi kişisel normlar tarafından desteklendiğinde artarak güçlenecektir.

- Varsayılan (Algılanan) Davranış Kontrolü: Algılanan kişisel çıkar bir fayda içeriyorsa ve kişisel normlar ile örtüşüyorsa girişim fikri uygulamaya geçebilecektir. Algılanan fırsatın kontrol edilebilirliği de dolaylı olarak girişimci davranışlarını etkilemektedir (Top 2006, s.233). Davranışı gösterecek kişinin söz konusu davranışı gösterebilmesinin kolaylığı veya zorluğuna olan inancıdır (Erten 2002, s.69). Varsayılan davranış kontrolü, girişimcilik eğiliminin gelişmesi ve girişim fikrinin uygulanması aşamalarında fırsat ve tehditlerin tespit edilmesi ve bu fırsatların değerlendirilerek kontrol edilmesine yönelik bir unsurdur. Eğer girişim düşüncesi risk unsurunu kontrol altına alıyorsa girişimci bu fikri gerçekleştirme eğilimi içinde olacaktır. 


\section{Değişkenler Arası İlişkiler}

Literatür incelendiğinde üniversite öğrencilerinin kişilik tipleri ile girişimcilik eğilimleri arasındaki ilişkiyi inceleyen veya girişimcilik eğilimi üzerinde demografik özelliklerin etkisini konu alan pek çok çalışma yapıldığ görülmektedir. Bu bağlamda, bu araştırma için literatür taranmış, değişkenler arası ilişkiler incelenmiş, araştırma modeli tasarlanmış ve aşağıdaki hipotezler formüle edilmiştir:

Bozkurt ve Erdurur (2013), Özdevecioğlu ve Karaca (2015), Kazaferoğlu (2017), Konaklığlu ve Kızanlıklı (2011), Uysal (2021), üniversite öğrencilerinin kişilik özellikleri ile girişimcilik eğilimleri arasındaki ilişkiyi araştırmışlardır. Çalışmaların sonuçları kişilik özelliklerinin girişimciliği pozitif yönde etkilediğini ortaya koymuştur.

Şeşen ve Basım (2012), İrmiş ve Barutçu, (2012), Salik ve Kaygın (2016), demografik faktörlerin ve öğrencilerin kişilik özelliklerinin öğrencilerin girişimcilik niyetlerini nasıl etkilediğini araştırmışlardır. Öğrencilerin demografik özelliklerinin girişimcilik eğilimlerini etkilediği bulunmuştur. Girişimcilik dersi alanların ve ailede bir girişimci rol modeli olanların girişimci kişilik özelliklerinin daha yüksek olduğu tespit edilmiştir.

\section{Araştırmanın Metodolojisi}

\section{Araştırmanın Amacı}

Bu çalışmanın temel amacı, üniversite öğrencilerinin kişilik tipleri ile girişimcilik eğilimleri arasındaki ilişkide demografik özelliklerin etkisini araştırmaktır.

\section{Araştırma Modeli ve Hipotezleri}

Bu literatür doğrultusunda hipotezler aşağıdaki gibi belirlenmiştir:

H1: Kişilik Tipleri, Girişimcilik Eğilimini etkiler.

H2: Kişilik Tipleri demografik değişkenlere göre anlamlı farklılık gösterir.

H3: Girişimcilik Eğilimleri demografik değişkenlere göre anlamlı farklılık gösterir. 


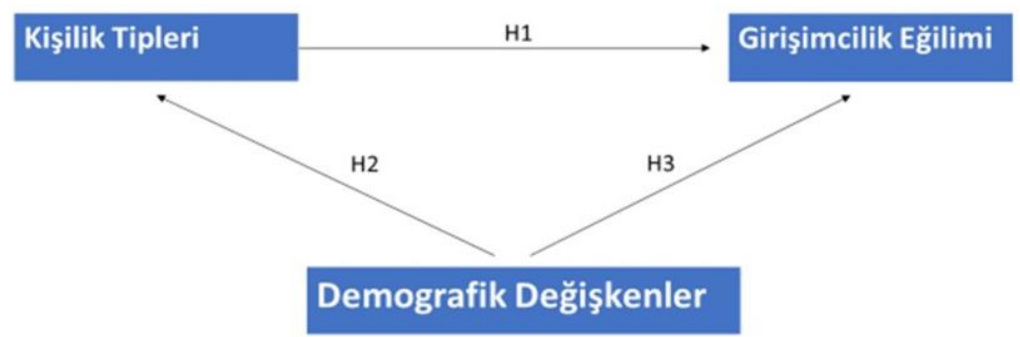

Şekil 1. Araştırma Modeli

\section{Araştırmanın Analiz Yöntemi}

Analizler SPSS 21.0 programı ile yapılmıştır ve \%95 güven düzeyinde çalışılmıştır. Maddeler içi ölçeklerden elde edilen basıklık ve çarpıklık değerlerinin +3 ile -3 arasında olması normal dağılım için yeterli görülmektedir (Groeneveld ve Meeden, 1984; Moors, 1986; Hopkins ve Weeks, 1990; De Carlo, 1997).

$\mathrm{Bu}$ nedenle analizlerde parametrik olan Bağımsız gruplar $\mathrm{t}$ testi, ANOVA testi, Tukey testi ve Pearson korelasyon testi kullanılmıştır. Ölçek puanlarının 2 gruplu değişkenlere göre farklılık gösterme durumu $t$ testi ile 3 ve daha fazla gruplu değişkenlere göre farklılık gösterme durumu ANOVA testi ile analiz edilmiştir. ANOVA testinde fark çıkması durumunda ikili karşılaştırma için Tukey testi kullanılmıştır. Ölçek puanları arasındaki ilişki Pearson korelasyon testi ile analiz edilmiştir. Ölçek puanları arasındaki etki ise Path analizinde Bootstrap tekniği ile analiz edilmiştir. Baron ve Kenny yönteminin güçlü bir yöntem olmadığını öne sürerek bu geleneksel yöntem yerine bootstrap tekniğine dayanan ve daha geçerli ve güvenilir sonuçlar veren modern yaklaşımın kullanılması gerektiğini öne sürmüşlerdir (Fritz ve MacKinnon, 2007; Hayes, 2018; Hayes 
ve Rockwood, 2017; Preacher ve Selig, 2012; Williams ve MacKinnon, 2008).

\section{Araştırmanın Evreni ve Örneklemi}

Araştırmanın evreni İstanbul ilinde faaliyet gösteren bir vakıf üniversitesi' nde 2020-2021 Eğitim Öğretim yılında öğrenim gören 900 öğrenci oluşturmaktadır. Çalışma ile ilgili olarak İstanbul Esenyurt Üniversitesi'nden 20.05.2021 tarihli ve 2021/06-09 No'lu gerekli etik kurul izni alınmıştır. Kolayda örneklem yöntemi kullanılarak 01 Mayıs - 01 Haziran 2021 tarihleri arasında 196 öğrenciye ulaşılmıştır. Örneklemi oluşturan öğrenci sayısını belirlemek için aşağıdaki formül kullanılmıştır. 900 öğrenciden oluşan evren için \%95 güven düzeyi ve $\% 5$ hata ile hesaplanan örneklem sayısı 87'dir. \%5 hata payı ile anakütleyi temsil edecek örneklem büyüklüğünün minimum 87 öğrenci olması gerektiği hesaplanmıştır.

$$
\mathrm{n}=\frac{\mathrm{N} \cdot \sigma_{0}^{2} Z_{\alpha}}{(\mathrm{N}-1) \cdot \mathrm{d}^{2}}
$$

N: Evren birim sayısı,

n: Örneklem büyüklüğü

P: Evrendeki $X^{\prime}$ in gözlenme oranı,

$\mathrm{Q}$ (1-P): X'in gözlenmeme oranı

$Z \alpha: \alpha=0.05,0.01,0.001$ için $1.96,2.58$ ve 3.28 değerleri

$\mathrm{d}=$ Örneklem hatası

$\sigma=$ Evren standart sapmasi

$\mathrm{t} \alpha, \mathrm{sd}=\mathrm{sd}$ serbestlik dereceli $\mathrm{t}$ dağılımı kritik değerleridir $(\mathrm{sd}=\mathrm{n}-1) . \mathrm{t} \alpha, \mathrm{sd}$ kritik değerleri sd= $\mathrm{n}-1 \rightarrow 5000$ olduğunda $\mathrm{Z} \alpha$ değerlerine eşit alınabilir (Özdamar, 2003:116- 118).

\section{Araştırmanın Veri Toplama Araçları}

Araştırmada kullanılan anket formu 3 bölümden oluşmaktadır. Birinci bölümde demografik özellikler, ikinci bölümde "Beş Faktör Kişilik Özellikleri Ölçeği", üçüncü bölümde "Girişimcilik Eğilimi Ölçeği" kullanılmıştır. Demografik bilgilerin yer aldığı cinsiyet, yaş, eğitim durumu, sınıf, anne 
baba eğitim durumu, ailede girişimci/girişimcilerin olup olmadığı, girişimcilik eğitimi alıp almadığı gibi soruların yer aldığı 11 soruluk bir form oluşturulmuştur.

Girişimcilik Eğilimi Ölçeği olarak, Yılmaz ve Sünbül (2009) tarafından geliştirilen "Üniversite Öğrencileri İçin Girişimcilik Ölçeği” kullanılmıştır. Girişimcilik eğitiminin girişimcilik eğilimlerinde etkisinin olup olmadığı ve ayrıca girişimcilik eğitiminin girişimcilik eğilimi unsurları (davranışa yönelik tutum, kişisel norm, varsayılan davranış kontrolü) üzerinde etkisinin olup olmadığı belirlenmeye çalışılmıştır. Leroy vd. (2009), tarafından uyarlanan beşli likert tipi ölçek kullanılmıtır. Ölçeğin güvenilirlik analizi sonucunda Cronbach's Alpha değeri 0.90 olarak belirlenmiştir.

Çalışmada öğrencilerin demografik özellikleri olarak; öğrencilerin başarı derecesi, anne-baba eğitim durumu, ailesinde girişimci olup olmadığı, varsa kimlerin olduğu, okulu bitirdikten sonraki mesleki idealleri, girişimcilik eğitimi alıp almadığı ve aldıkları girişimcilik eğitiminin onları girişimciliğe yönlendirdiğini düşünüp düşünmedikleri ile ilgili bilgilere ulaşılmaya çalışılmıştır. Girişimcilik eğilimi (mesleki ideali) üzerinde etkili olan faktörler öğrencilerin anne-baba eğitim düzeyi, ailede girişimci olup olmadığı durumu, girişimcilik dersi alıp almadığı ve aldığ 1 girişimcilik dersinin girişimciliğe yönelme durumuna katkısı belirlenmeye çal1şılmıştır.

Beş Faktör Kişilik Ölçeği, John, Donahue ve Kentle (1991) tarafından geliştirilen Beş Büyük Kişilik Ölçeği (BFI) kullanılmıştır. Ölçeğin Türkçe uyarlaması Sümer vd. (2005) tarafından yapılmıştır. 44 sorudan oluşan ölçek, kişilik özelliklerini 'Dışadönüklük', 'Nevrotiklik', 'Sorumluluk', 'Uyumluluk' ve 'Deneyime Açılık' olmak üzere beş alt boyutta değerlendirmektedir.

2008).

\section{Güvenirlik Analizi}

Cronbach's alfa katsayısı ölçeğin güvenirlik düzeyini vermektedir. Katsayı 0 ile 1 arasında değişmektedir. Alfa $(\alpha)$ katsayısına bagłı olarak ölçeğin güvenilirligĭ ș,u șekilde yorumlanmaktadır (Nunnally, 1967, 248). 
- $.00 \leq \alpha<.40$ ise ölçek güvenilir degĭldir,

- .40 $\leq \alpha<.60$ ise ölçegin güvenirliğ düșük,

- $.60 \leq \alpha<.80$ ise ölçek oldukça güvenilir,

- $.80 \leq \alpha<1.00$ ise ölçek yüksek derecede güvenilir bir ölçektir.

Tablo 1. Kişilik Tipleri ile Girişimcilik Eğilimlerine Ait Betimsel İstatistikler ve Normallik Testi

\begin{tabular}{lllllllll}
\hline & $\mathbf{n}$ & Minimum & Maximum & Ort & ss & Çarpıklık Basıklık $\begin{array}{c}\text { Cron- } \\
\text { bach's } \\
\text { Alpha }\end{array}$ \\
\hline Davranışa Yönelik Tutum & 196 & 1,40 & 5,00 & 3,80 & 0,78 &,- 666 &, 314 &, 901 \\
Varsayılan Davranış Kontrolü & 196 & 1,63 & 5,00 & 3,90 & 0,69 &,- 827 &, 881 &, 810 \\
Kişisel Norm & 196 & 1,25 & 5,00 & 3,51 & 0,71 &,- 264 &, 764 &, 861 \\
\hline Dişadönüklük & 196 & 1,50 & 5,00 & 3,57 & 0,50 &,- 598 & 2,239 &, 787 \\
Nevrotiklik & 196 & 1,75 & 5,00 & 3,06 & 0,53 &, 576 &, 736 &, 717 \\
Sorumluluk & 196 & 1,56 & 5,00 & 3,47 & 0,45 &,- 299 & 2,258 &, 755 \\
Uyumluluk & 196 & 1,67 & 5,00 & 3,31 & 0,46 &, 230 & 1,479 &, 586 \\
Deneyime Açıklı & 196 & 1,90 & 5,00 & 3,73 & 0,47 &,- 348 &, 707 &, 696 \\
\hline
\end{tabular}

Katılımcıların kişilik tipleri ile girişimcilik eğilimlerinden elde edilen çarpıklık ve basıklık değerleri +3 ile -3 arasında olduğundan normallik sağlanmış olup analizlerimizde parametrik olan test teknikleri kullanılmiştır.

\section{Bulgular}

Toplanan verilerin analizinden elde edilen sonuçlar aşağıda sunulmuştur. Tablo 2' de demografik değişkenlere ait bulgular yer almaktadır.

Tablo 2. Demografik Değişkenler

\begin{tabular}{llll}
\hline & & $\mathbf{n}$ & $\mathbf{\%}$ \\
\hline \multirow{2}{*}{ Cinsiyet } & Kadın & 46 & 23,5 \\
& Erkek & 150 & 76,5 \\
\hline \multirow{2}{*}{ Yaş } & $17-20$ & 40 & 20,4 \\
& $21-24$ & 150 & 76,5 \\
& & $25-28$ & 2,6 \\
Eğitim Durumu & 28 yaş üzeri & 1 &, 5 \\
\hline \multirow{2}{*}{ Sınıfınız } & Ön lisans & 1 &, 5 \\
& Lisans & 194 & 99,5 \\
\hline Annenizin Eğitim Durumu & 1 & 6 & 3,1 \\
& 2 & 28 & 14,3 \\
& 3 & 115 & 58,7 \\
\end{tabular}




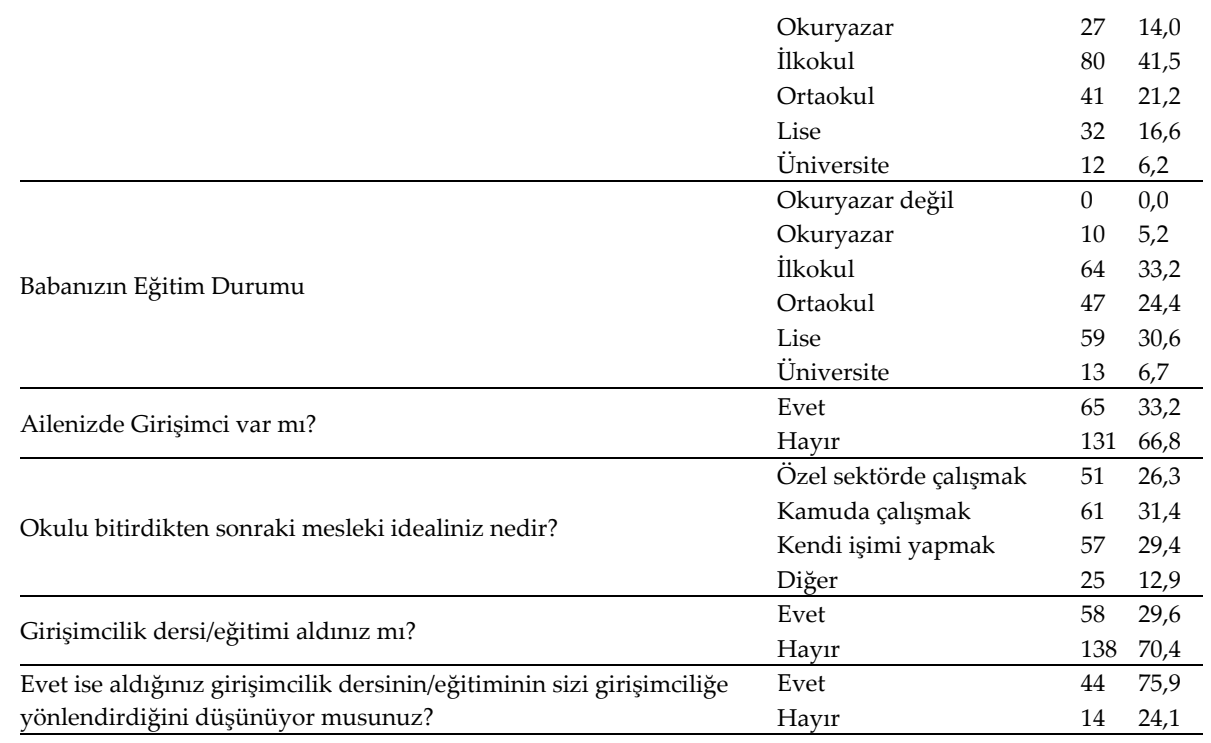

Tablo 2' de girişimcilik dersi/eğitimi almış olanların oranı $\% 29,6^{\prime}$ dur. Bunun sebebi eğitimde girişimcilik dersinin zorunlu olarak yeni düzenlenmiş olmasıdır.

Tablo 3. Kişilik Tipleri ile Girişimcilik Ĕ̆ilimleri Arasındaki İlişkinin İncelenmesi

\begin{tabular}{llll}
\hline & Davranışa Yönelik Tutum & Varsayılan Davranış Kontrolü & Kişisel Norm \\
\hline Dışadönüklük &, $291^{* *}$ &, $300^{* *}$ &, $269^{* *}$ \\
Nevrotiklik &, 112 &, 087 &, 055 \\
Sorumluluk &, $212^{* *}$ &, $223^{* *}$ &, 099 \\
Uyumluluk &, 125 &, $157^{*}$ &, $170^{*}$ \\
Deneyime Açıllık &, $464^{* *}$ &, $496^{* *}$ &, $454^{* *}$ \\
\hline
\end{tabular}

${ }^{*} p<0,05 ;{ }^{* *} p<0,01 ; \quad$ Pearson Korelasyon katsayısi: $\quad 0-0,299=z a y \imath f, \quad 0,300$ 0,599=orta; $\quad 0,600-0,799=$ güçlï; $0,800-1=$ =çok güçlï

Dışadönüklük ile Davranışa Yönelik Tutum arasında pozitif yönlü zayıf bir ilişki $(r=0,291)$; Varsayılan Davranış Kontrolü arasında pozitif yönlü orta bir ilişki $(\mathrm{r}=0,300)$; Kişisel Norm arasında pozitif yönlü zayıf bir ilişki $(\mathrm{r}=0,269)$ bulunmaktadır.

Sorumluluk ile Davranışa Yönelik Tutum arasında pozitif yönlü zayıf bir ilişki $(r=0,212)$; Varsayılan Davranış Kontrolü arasında pozitif yönlü zayıf bir ilişki $(\mathrm{r}=0,223)$ bulunmaktadır. 
Uyumluluk ile Varsayılan Davranış Kontrolü arasında pozitif yönlü zayıf bir ilişki $(r=0,157)$; Kişisel Norm arasında pozitif yönlü zayıf bir ilişki $(\mathrm{r}=0,170)$ bulunmaktadir.

Deneyime Açıklık ile Davranışa Yönelik Tutum arasında pozitif yönlü orta bir ilişki $(\mathrm{r}=0,464)$; Varsayılan Davranış Kontrolü arasında pozitif yönlü orta bir ilişki $(\mathrm{r}=0,496)$; Kişisel Norm arasında pozitif yönlü orta bir ilişki $(\mathrm{r}=0,454)$ bulunmaktadır.

Tablo 4. Kişilik Tiplerinin, Girişimcilik Eğilimlerine Etkisinin İncelenmesi

\begin{tabular}{lllllll}
\hline Parameter & & & Beta & Lower & Upper & p \\
\hline Davranışa Yönelik Tutum & $<---$ & Dişadönüklük &, 086 &,- 048 &, 231 &, 280 \\
Varsayılan Davranış Kontrolü & $<---$ & Dişadönüklük &, 073 &,- 045 &, 201 &, 295 \\
Kişisel Norm & $<---$ & Dişadönüklük &, 069 &,- 044 &, 198 &, 312 \\
Davranışa Yönelik Tutum & $<---$ & Nevrotiklik &,- 008 &,- 140 &, 116 &, 896 \\
Varsayılan Davranış Kontrolü & $<---$ & Nevrotiklik &,- 070 &,- 206 &, 060 &, 366 \\
Kişisel Norm & $<---$ & Nevrotiklik &,- 056 &,- 192 &, 074 &, 490 \\
Davranışa Yönelik Tutum & $<---$ & Sorumluluk &, 041 &,- 067 &, 153 &, 558 \\
Varsayılan Davranı̧̧ Kontrolü & $<---$ & Sorumluluk &, 052 &,- 056 &, 172 &, 441 \\
Kişisel Norm & $<---$ & Sorumluluk &,- 116 &,- 224 &,- 005 &, 088 \\
Davranışa Yönelik Tutum & $<---$ & Uyumluluk &,- 090 &,- 213 &, 040 &, 251 \\
Varsayılan Davranış Kontrolü & $<---$ & Uyumluluk &,- 038 &,- 156 &, 094 &, 663 \\
Kişisel Norm & $<---$ & Uyumluluk &, 051 &,- 083 &, 189 &, 545 \\
Davranışa Yönelik Tutum & $<---$ & Deneyime Açıklık &, 439 &, 328 &, 551 &, $000^{*}$ \\
Varsayılan Davranış Kontrolü & $<---$ & Deneyime Açıklık &, 469 &, 358 &, 565 &, $001^{*}$ \\
Kişisel Norm & $<---$ & Deneyime Açıklık &, 463 &, 342 &, 577 &, $000^{*}$ \\
\hline
\end{tabular}

${ }^{*} p<0,05$

Deneyime Açıklı, Davranışa Yönelik Tutumu pozitif etkilemektedir (Beta=0,439).

Deneyime Açıklık, Varsayılan Davranış Kontrolünü pozitif etkilemektedir (Beta=0,469).

Deneyime Açıklık, Kişisel Normu pozitif etkilemektedir (Beta=0,463). 


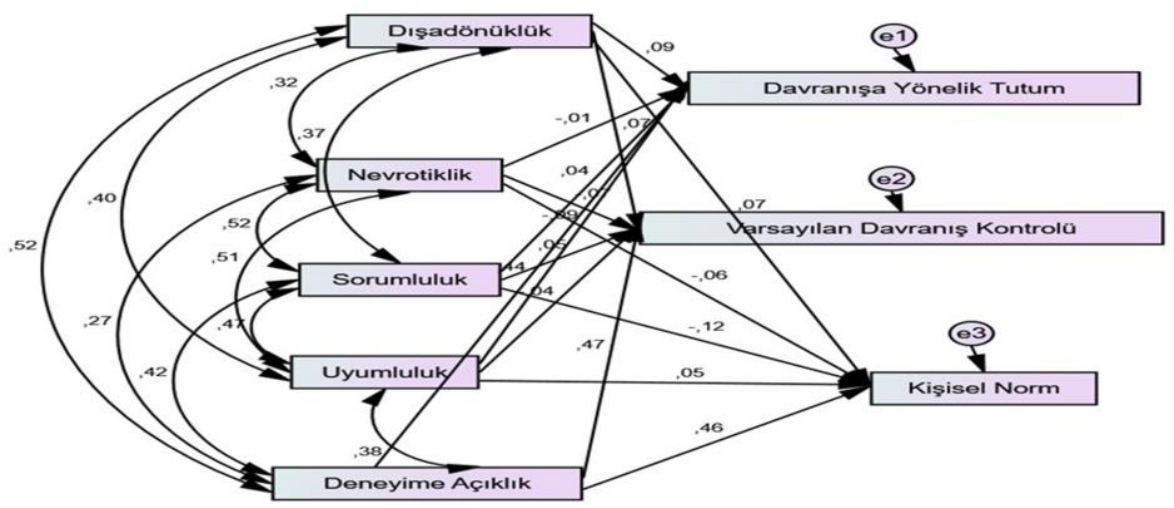

Şekil 2. Kişilik Tiplerinin, Girişimcilik Ĕ̆ilimlerine Etkisinin İncelenmesi PATH Analizi

Tablo 5. Kişilik Tipleri ile Girişimcilik Ĕ̆ilimlerinin Cinsiyet Açısından İncelenmesi

\begin{tabular}{|c|c|c|c|c|c|c|}
\hline & \multicolumn{4}{|c|}{ Cinsiyet } & \multirow{3}{*}{$\mathbf{t}$} & \multirow{3}{*}{$\mathbf{p}$} \\
\hline & \multicolumn{2}{|c|}{ Kadın } & \multicolumn{2}{|c|}{ Erkek } & & \\
\hline & Ort & ss & Ort & ss & & \\
\hline Davranışa Yönelik Tutum & 3,77 & 79 & 3,81 & ,79 &,- 336 & ,737 \\
\hline Varsayılan Davranış Kontrolü & 3,93 &, 59 & 3,90 & ,71 & ,290 & ,772 \\
\hline Kişisel Norm & 3,59 & 69 & 3,49 & ,72 & ,897 & ,371 \\
\hline Dışadönüklük & 3,63 & 42 & 3,55 &, 52 & ,993 & ,322 \\
\hline Nevrotiklik & 3,05 &, 53 & 3,06 &, 53 &,- 084 & ,933 \\
\hline Sorumluluk & 3,51 & 49 & 3,45 & 44 & ,703 & ,483 \\
\hline Uyumluluk & 3,37 & , 48 & 3,29 & ,45 & 1,015 & ,311 \\
\hline Deneyime Açıklık & 3,72 & 45 & 3,73 & ,48 &,- 234 & ,815 \\
\hline
\end{tabular}

\section{${ }^{*} p<0,05$ Bă̆ımsız gruplar t testi}

Kadın ile erkekler arasında kişilik tipleri açısından istatistiksel olarak anlamlı farklılık bulunmamaktadır $(p>0,05)$.

Kadın ile erkekler arasında girişimcilik eğilimleri açısından istatistiksel olarak anlamlı farklılık bulunmamaktadır ( $p>0,05)$.

Tablo 6. Kişilik Tipleri ile Girişimcilik Eğilimlerinin Yaş Açısından İncelenmesi

\begin{tabular}{|c|c|c|c|c|c|c|c|c|}
\hline & \multicolumn{6}{|l|}{ Yaş } & \multirow{3}{*}{ F } & \multirow{3}{*}{$\mathbf{p}$} \\
\hline & \multicolumn{2}{|c|}{$17-20$} & \multicolumn{2}{|c|}{$21-24$} & \multicolumn{2}{|c|}{25 yaş ve üzeri } & & \\
\hline & Ort & ss & Ort & ss & Ort & ss & & \\
\hline Davranışa Yönelik Tutum & 3,91 & 79 & 3,76 & 79 & 4,00 & 53 & ,761 & ,469 \\
\hline Varsayılan Davranış Kontrolü & 4,05 & ,70 & 3,86 & 69 & 3,96 &, 55 & 1,205 & ,302 \\
\hline Kişisel Norm & 3,48 & 68 & 3,51 & ,72 & 3,78 & ,82 & ,473 & ,624 \\
\hline Dişadönüklük & 3,56 &, 58 & 3,58 & 48 & 3,48 & ,32 & 119 & ,888 \\
\hline Nevrotiklik & 3,08 & ,61 & 3,06 &, 51 & 2,88 & ,16 & ,387 & ,680 \\
\hline Sorumluluk & 3,41 &, 54 & 3,48 & ,43 & 3,41 & 24 & ,466 & 628 \\
\hline
\end{tabular}




\begin{tabular}{lllllllll} 
Uyumluluk & 3,33 &, 55 & 3,31 &, 44 & 3,17 &, 15 &, 313 &, 732 \\
Deneyime Açıklık & 3,75 &, 58 & 3,73 &, 45 & 3,63 &, 30 &, 171 &, 843 \\
\hline
\end{tabular}

${ }^{*} p<0,05$ ANOVA testi

Yaşı farklı olan gruplar arasında kişilik tipleri açısından istatistiksel olarak anlamlı farklılık bulunmamaktadir ( $p>0,05)$.

Yaşı farklı olan gruplar arasında girişimcilik eğilimleri açısından istatistiksel olarak anlamlı farklilik bulunmamaktadır $(p>0,05)$.

Tablo 7. Kişilik Tipleri ile Girişimcilik Ĕ̆ilimlerinin Sınıf Açısından İncelenmesi

\begin{tabular}{|c|c|c|c|c|c|c|c|c|c|c|c|}
\hline & \multicolumn{8}{|c|}{ Sinıfiniz } & \multirow{3}{*}{$\mathbf{F}$} & \multirow{3}{*}{$\mathbf{p}$} & \multirow{3}{*}{$\begin{array}{l}\text { İkili } \\
\text { karşılaştırma }\end{array}$} \\
\hline & \multicolumn{2}{|c|}{1} & \multicolumn{2}{|l|}{2} & \multicolumn{2}{|l|}{3} & \multicolumn{2}{|l|}{4} & & & \\
\hline & Ort & ss & Ort & ss & Ort & ss & Ort & ss & & & \\
\hline Davranışa Yönelik Tutum & 3,52 & 1,17 & 3,80 & 91 & 3,84 & ,71 & 3,74 & 84 & 455 & ,714 & \\
\hline Varsayılan Davranış Kontrolü & 3,67 & 0,80 & 3,85 & ,73 & 3,90 & 69 & 3,97 & 65 & 447 & ,720 & \\
\hline Kişisel Norm & 3,33 & 1,07 & 3,44 & 67 & 3,59 & ,66 & 3,39 &, 80 & 1,113 & ,345 & \\
\hline Dışadönüklük & 3,23 & 0,91 & 3,49 & 60 & 3,59 & ,44 & 3,61 & 49 & 1,395 & ,246 & \\
\hline Nevrotiklik & 2,90 & 0,23 & 3,28 & 60 & 3,02 &, 53 & 3,03 & 48 & 2,104 & 101 & \\
\hline Sorumluluk & 3,37 & 0,27 & 3,47 & 63 & 3,51 & 44 & 3,36 &, 34 & 1,448 & 230 & \\
\hline Uyumluluk & 3,07 & 0,29 & 3,52 & 60 & 3,31 & 44 & 3,21 &, 37 & 3,460 &, $017^{*}$ & $2>4$ \\
\hline Deneyime Açıklık & 3,37 & 0,57 & 3,79 &, 56 & 3,73 & 46 & 3,74 & 43 & 1,363 & ,255 & \\
\hline
\end{tabular}

${ }^{*} p<0,05$ ANOVA testi

Sınıfı farklı olan gruplar arasında kişilik tipleri açısından istatistiksel olarak anlamlı farklılık bulunmamaktadir ( $p>0,05)$.

Sinıfi farklı olan gruplar arasında Uyumluluk açısından istatistiksel olarak anlamlı farklılık bulunmaktadır $(p<0,05)$. Buna göre 2.sinıf olanların puan ortalaması en yüksek iken 1.sınf olanların ortalaması en düşüktür.

Tablo 8. Kişilik Tipleri ile Girişimcilik Ĕ̆ilimlerinin Anne Ĕ̆itim Durumu Açısından Incelenmesi

\begin{tabular}{|c|c|c|c|c|c|c|c|c|c|c|c|c|c|}
\hline & \multicolumn{10}{|c|}{ Annenizin Eğitim Durumu } & \multirow{3}{*}{$\mathbf{F}$} & \multirow{3}{*}{$\mathbf{p}$} & \multirow{3}{*}{$\begin{array}{l}\text { İkili } \\
\text { karşılaştırma }\end{array}$} \\
\hline & \multicolumn{4}{|c|}{ Okuryazar İlkokul } & \multicolumn{2}{|c|}{ Ortaokul } & \multicolumn{2}{|l|}{ Lise } & \multicolumn{2}{|c|}{ Üniversite } & & & \\
\hline & $\overline{\text { Ort }}$ & ss & Ort & ss & Ort & ss & Ort & ss & Ort & ss & & & \\
\hline $\begin{array}{l}\text { Davranışa Yönelik Tu- } \\
\text { tum }\end{array}$ & 4,11 & 80 & 3,63 & 83 & 3,96 & ,70 & 3,80 & ,78 & 3,86 &, 50 & 2,509 &, $043^{*}$ & $1>2$ \\
\hline $\begin{array}{l}\text { Varsayılan Davranış } \\
\text { Kontrolü }\end{array}$ & 4,31 & 69 & 3,75 & ,65 & 4,00 & 69 & 3,91 & ,73 & 3,73 & ,42 & 3,965 &, $004^{*}$ & $1>2$ \\
\hline Kişisel Norm & 3,82 & ,78 & 3,36 & ,65 & 3,65 & ,76 & 3,50 & ,76 & 3,53 & ,42 & 2,682 &, $033^{*}$ & $1>2$ \\
\hline Dişadönüklük & 3,67 & ,47 & 3,58 &, 52 & 3,63 & ,35 & 3,50 & 65 & 3,38 &, 37 & 1,003 &, 407 & \\
\hline Nevrotiklik & 3,13 & ,62 & 3,02 &, 50 & 3,06 &, 52 & 3,17 & 60 & 2,89 & ,36 & 0,901 & 464 & \\
\hline Sorumluluk & 3,60 & 47 & 3,45 & 38 & 3,48 &, 37 & 3,41 & 65 & 3,45 & ,42 & 0,802 &, 526 & \\
\hline Uyumluluk & 3,42 & 48 & 3,32 & 44 & 3,21 & 40 & 3,36 &, 54 & 3,19 &, 50 & 1,150 & ,334 & \\
\hline Deneyime Açıklık & 3,99 & ,33 & 3,69 &, 50 & 3,73 & 42 & 3,74 &, 52 & 3,53 & 43 & 2,779 &, $028^{*}$ & $1>2,1>5$ \\
\hline
\end{tabular}

${ }^{*} p<0,05$ ANOVA testi

Annesinin eğitim durumu farklı olan gruplar arasında Davranışa Yönelik Tutum açısından istatistiksel olarak anlamlı farklılık bulunmaktadır 
$(\mathrm{p}<0,05)$. Buna göre annesi okuryazar olanların puan ortalaması en yüksek iken ilkokul mezunu olanların ortalaması en düşüktür.

Annesinin eğitim durumu farklı olan gruplar arasında Varsayılan Davranış Kontrolü açısından istatistiksel olarak anlamlı farklılık bulunmaktadır $(p<0,05)$. Buna göre annesi okuryazar olanların puan ortalaması en yüksek iken üniversite mezunu olanların ortalaması en düşüktür.

Annesinin eğitim durumu farklı olan gruplar arasında Kişisel Norm açısından istatistiksel olarak anlamlı farklılık bulunmaktadır $(\mathrm{p}<0,05)$. Buna göre annesi okuryazar olanların puan ortalaması en yüksek iken ilkokul mezunu olanların ortalaması en düşüktür.

Annesinin eğitim durumu farklı olan gruplar arasında Deneyime Açılık açısından istatistiksel olarak anlamlı farklılık bulunmaktadır $(\mathrm{p}<0,05)$. Buna göre annesi okuryazar olanların puan ortalaması en yüksek iken üniversite mezunu olanların ortalaması en düşüktür.

Tablo 9. Kişilik Tipleri ile Girişimcilik Eğilimlerinin Baba Eğitim Durumu Açısından Incelenmesi

\begin{tabular}{|c|c|c|c|c|c|c|c|c|c|c|c|c|c|}
\hline & \multicolumn{10}{|c|}{ Babanızın Eğitim Durumu } & \multirow{3}{*}{$\mathbf{F}$} & \multirow{3}{*}{ p } & \multirow{3}{*}{$\begin{array}{l}\text { İkili } \\
\text { karşılaştırma }\end{array}$} \\
\hline & \multicolumn{2}{|c|}{ Okuryaza } & \multicolumn{2}{|c|}{ İlkokul } & \multicolumn{2}{|c|}{ Ortaokul } & \multicolumn{2}{|l|}{ Lise } & \multicolumn{2}{|c|}{ Üniversite } & & & \\
\hline & Ort & ss & Ort & ss & Ort & ss & Ort & ss & Ort & ss & & & \\
\hline $\begin{array}{l}\text { Davranışa Yönelik Tu- } \\
\text { tum }\end{array}$ & 4,13 & ,86 & 3,53 & ,85 & 4,00 & ,74 & 3,82 & ,73 & 4,09 &, 55 & 3,727 &, $006^{*}$ & $2<3$ \\
\hline $\begin{array}{l}\text { Varsayılan Davranış } \\
\text { Kontrolü }\end{array}$ & 4,19 & ,98 & 3,66 & ,71 & 4,14 &, 54 & 3,87 & 68 & 4,11 & 41 & 4,362 &, $002^{*}$ & $2<3$ \\
\hline Kişisel Norm & 3,63 & 79 & 3,30 & ,71 & 3,70 & ,67 & 3,53 & ,74 & 3,70 & ,44 & 2,570 &, $039^{*}$ & $2<3$ \\
\hline Dışadönüklük & 3,59 & 63 & 3,57 & ,48 & 3,65 & ,45 & 3,51 & ,55 & 3,52 & ,43 & 0,556 & ,695 & \\
\hline Nevrotiklik & 3,23 & 64 & 3,01 &, 51 & 3,02 &, 57 & 3,08 &, 51 & 3,16 &, 54 & 0,611 & 655 & \\
\hline Sorumluluk & 3,46 & 44 & 3,48 & ,43 & 3,46 &, 50 & 3,44 & ,47 & 3,57 & ,36 & 0,250 & ,910 & \\
\hline Uyumluluk & 3,43 & 47 & 3,29 & ,47 & 3,30 & 48 & 3,30 & ,43 & 3,33 &, 50 & 0,234 & ,919 & \\
\hline Deneyime Açıklık & 3,76 &, 46 & 3,67 &, 52 & 3,82 &, 48 & 3,70 &, 46 & 3,85 &, 26 & 0,970 &, 425 & \\
\hline
\end{tabular}

${ }^{*} p<0,05$ ANOVA testi

Babasının eğitim durumu farklı olan gruplar arasında Davranışa Yönelik Tutum açısından istatistiksel olarak anlamlı farklılık bulunmaktadır $(p<0,05)$. Buna göre babası okuryazar olanların puan ortalaması en yüksek iken ilkokul mezunu olanların ortalaması en düşüktür.

Babasının eğitim durumu farklı olan gruplar arasında Varsayılan Davranış Kontrolü açısından istatistiksel olarak anlamlı farklılık bulunmaktadır $(\mathrm{p}<0,05)$. Buna göre babası okuryazar olanların puan ortalaması en yüksek iken ilkokul mezunu olanların ortalaması en düşüktür. 
Babasının eğitim durumu farklı olan gruplar arasında Kişisel Norm açısından istatistiksel olarak anlamlı farklılık bulunmaktadır $(\mathrm{p}<0,05)$. Buna göre babası ortaokul ya da üniversite mezunu olanların puan ortalaması en yüksek iken ilkokul mezunu olanların ortalaması en düşüktür.

Babasının eğitim durumu farklı olan gruplar arasında girişimcilik eğilimleri açısından istatistiksel olarak anlamlı farklılık bulunmamaktadır $(\mathrm{p}>0,05)$.

Tablo 10. Kişilik Tipleri ile Girişimcilik Eğilimlerinin Ailesinde Girişimci Olma Durumu Açısından Incelenmesi

\begin{tabular}{|c|c|c|c|c|c|c|}
\hline & \multicolumn{4}{|c|}{ Ailenizde Girişimci var mı? } & \multirow{3}{*}{$t$} & \multirow{3}{*}{$\mathbf{p}$} \\
\hline & \multicolumn{2}{|c|}{ Evet } & \multicolumn{2}{|c|}{ Hayır } & & \\
\hline & Ort & ss & Ort & ss & & \\
\hline Davranışa Yönelik Tutum & 4,04 & 65 & 3,68 & ,82 & 3,282 &, $001^{*}$ \\
\hline Varsayılan Davranış Kontrolü & 4,15 &, 53 & 3,78 & ,72 & 3,686 &, $000^{*}$ \\
\hline Kişisel Norm & 3,77 &, 57 & 3,38 & ,74 & 3,794 &, $000^{*}$ \\
\hline Dışadönüklük & 3,65 & 46 & 3,53 &, 51 & 1,566 & 119 \\
\hline Nevrotiklik & 3,09 &, 53 & 3,04 &, 53 & 0,686 & ,493 \\
\hline Sorumluluk & 3,44 & 46 & 3,48 & 44 & $-0,486$ & 628 \\
\hline Uyumluluk & 3,33 & 45 & 3,30 & 46 & 0,438 & 662 \\
\hline Deneyime Açıklık & 3,77 & ,43 & 3,71 & ,49 & 0,856 & 393 \\
\hline
\end{tabular}

${ }^{*} p<0,05$ Bă̆ımsız gruplart testi

Ailesinde girişimci olma durumu farklı olan gruplar arasında Davranışa Yönelik Tutum açısından istatistiksel olarak anlamlı farklılık bulunmaktadır $(\mathrm{p}<0,05)$. Buna göre ailesinde girişimci olanların puan ortalaması daha yüksektir.

Ailesinde girişimci olma durumu farklı olan gruplar arasında Varsayılan Davranış Kontrolü açısından istatistiksel olarak anlamlı farklılık bulunmaktadır $(\mathrm{p}<0,05)$. Buna göre ailesinde girişimci olanların puan ortalaması daha yüksektir.

Ailesinde girişimci olma durumu farklı olan gruplar arasında Kişisel Norm açısından istatistiksel olarak anlamlı farklılık bulunmaktadır $(p<0,05)$. Buna göre ailesinde girişimci olanların puan ortalaması daha yüksektir.

Ailesinde girişimci olma durumu farklı olan gruplar arasında girişimcilik eğilimleri açısından istatistiksel olarak anlamlı farklılık bulunmamaktadır $(\mathrm{p}>0,05)$. 
Tablo 11. Kişilik Tipleri ile Girişimcilik Ĕ̆ilimlerinin Okulu Bitirdikten Sonraki Mesleki İdeal Açısından Incelenmesi

\begin{tabular}{|c|c|c|c|c|c|c|c|c|c|c|c|}
\hline & \multicolumn{8}{|c|}{$\begin{array}{l}\text { Okulu bitirdikten sonraki mesleki idealiniz ne- } \\
\text { dir? }\end{array}$} & \multirow{3}{*}{ F } & \multirow{3}{*}{$\mathrm{p}$} & \multirow{3}{*}{$\begin{array}{l}\text { İkili } \\
\text { karşılaştırma }\end{array}$} \\
\hline & \multicolumn{2}{|c|}{$\begin{array}{l}\text { Özel sek- } \\
\text { törde çalış- } \\
\text { mak }\end{array}$} & \multicolumn{2}{|c|}{$\begin{array}{l}\text { Kamuda } \\
\text { çalışmak }\end{array}$} & \multicolumn{2}{|c|}{$\begin{array}{l}\text { Kendi } \\
\text { işimi yap- } \\
\text { mak }\end{array}$} & \multicolumn{2}{|c|}{ Diğer } & & & \\
\hline & Ort & ss & Ort & ss & Ort & ss & Ort & ss & & & \\
\hline $\begin{array}{l}\text { Davranışa Yöne- } \\
\text { lik Tutum }\end{array}$ & 3,81 & 65 & 3,56 & 80 & 4,23 & 63 & 3,40 & ,90 & 11,236 &, $000^{*}$ & $1<3 ; 2<3 ; 3>4$ \\
\hline $\begin{array}{l}\text { Varsayılan Dav- } \\
\text { ranış Kontrolü }\end{array}$ & 4,04 & ,60 & 3,70 & ,69 & 4,15 & ,63 & 3,58 & ,73 & 7,424 &, $000^{*}$ & $1>2 ; 1>4 ; 2<3 ; 3>4$ \\
\hline Kişisel Norm & 3,68 & 62 & 3,23 & 67 & 3,71 & 73 & 3,38 & ,76 & 6,355 &, $000^{*}$ & $1>2 ; 2<3$ \\
\hline Dışadönüklük & 3,55 & ,40 & 3,58 &, 55 & 3,63 & ,45 & 3,42 & 64 & 1,026 & ,382 & \\
\hline Nevrotiklik & 2,94 & ,49 & 3,01 &, 51 & 3,23 &, 58 & 3,08 & ,46 & 3,116 &, $027^{*}$ & $1<3$ \\
\hline Sorumluluk & 3,46 & ,37 & 3,40 & ,52 & 3,55 & ,47 & 3,44 & ,34 & 1,170 & ,322 & \\
\hline Uyumluluk & 3,26 & ,42 & 3,33 & ,41 & 3,40 &, 54 & 3,18 & ,44 & 1,594 & 192 & \\
\hline Deneyime Açıklık & 3,73 & ,44 & 3,65 & 47 & 3,84 & 49 & 3,68 &, 52 & 1,775 & 153 & \\
\hline
\end{tabular}

*p<0,05 ANOVA testi

Okulu bitirdikten sonraki mesleki ideali farklı olan gruplar arasında Davranışa Yönelik Tutum açısından istatistiksel olarak anlamlı farklılık bulunmaktadır $(\mathrm{p}<0,05)$. Buna göre ideali kendi işini yapmak olanların puan ortalaması en yüksek iken diğer olanların ortalaması en düşüktür.

Okulu bitirdikten sonraki mesleki ideali farklı olan gruplar arasında Varsayılan Davranış Kontrolü açısından istatistiksel olarak anlamlı farklılık bulunmaktadır $(\mathrm{p}<0,05)$. Buna göre ideali kendi işini yapmak olanların puan ortalaması en yüksek iken diğer olanların ortalaması en düşüktür.

Okulu bitirdikten sonraki mesleki ideali farklı olan gruplar arasında Kişisel Norm açısından istatistiksel olarak anlamlı farklılık bulunmaktadır $(p<0,05)$. Buna göre ideali kendi işini yapmak olanların puan ortalaması en yüksek iken kamuda çalışmak olanların ortalaması en düşüktür.

Okulu bitirdikten sonraki mesleki ideali farklı olan gruplar arasında Nevrotiklik açısından istatistiksel olarak anlamlı farklılık bulunmaktadır $(p<0,05)$. Buna göre ideali kendi işini yapmak olanların puan ortalaması en yüksek iken özel sektörde çalışmak olanların ortalaması en düşüktür.

Tablo 12. Kişilik Tipleri ile Girişimcilik Ĕ̆ilimlerinin Girişimcilik Dersi/Eğitimi Alma Durumu Açısından İncelenmesi

\begin{tabular}{|c|c|c|c|c|c|c|}
\hline & \multicolumn{4}{|c|}{ Girişimcilik dersi/eğitimi aldınız mı? } & \multirow{3}{*}{$\mathbf{t}$} & \multirow{3}{*}{$\mathbf{p}$} \\
\hline & \multicolumn{2}{|c|}{ Evet } & \multicolumn{2}{|c|}{ Hayır } & & \\
\hline & Ort & ss & Ort & ss & & \\
\hline Davranışa Yönelik Tutum & 3,88 & 83 & 3,77 & ,77 & 879 & ,381 \\
\hline
\end{tabular}


Varsayılan Davranış Kontrolü

Kişisel Norm

\begin{tabular}{llllll}
4,06 &, 69 & 3,84 &, 67 & 2,152 &, $033^{*}$ \\
3,72 &, 76 & 3,42 &, 67 & 2,782 &, $006^{*}$ \\
3,62 &, 44 & 3,55 &, 52 &, 974 &, 331 \\
3,03 &, 53 & 3,07 &, 53 &,- 393 &, 695 \\
3,44 &, 42 & 3,48 &, 46 &,- 525 &, 600 \\
3,32 &, 40 & 3,30 &, 48 &, 243 &, 808 \\
3,80 &, 45 & 3,70 &, 48 & 1,351 &, 178 \\
\hline
\end{tabular}

Dışadönüklük

Nevrotiklik

Sorumluluk

Uyumluluk

3,80

Deneyime Açıklık

${ }^{*} p<0,05 \quad$ Bă̆ımsız gruplar t testi

Girişimcilik dersi/eğitimi alma durumu farklı olan gruplar arasında Varsayılan Davranış Kontrolü açısından istatistiksel olarak anlamlı farkl1lık bulunmaktadır $(p<0,05)$. Buna göre girişimcilik dersi/eğitimi almış olanların puan ortalaması daha yüksektir.

Girişimcilik dersi/eğitimi alma durumu farklı olan gruplar arasında Kişisel Norm açısından istatistiksel olarak anlamlı farklılık bulunmaktadır $(p<0,05)$. Buna göre girişimcilik dersi/eğitimi almış olanların puan ortalaması daha yüksektir.

Girişimcilik dersi/eğitimi alma durumu farklı olan gruplar arasında girişimcilik eğilimleri açısından istatistiksel olarak anlamlı farklılık bulunmamaktadır $(\mathrm{p}>0,05)$.

Tablo 13. Kişilik Tipleri ile Girişimcilik Eğilimlerinin Alınan Girişimcilik Dersi/Ĕ̆gitiminin Kendisini Girişimciliğe Yönlendirdiğini Dü̈sünme Durumu Açısından İncelenmesi

\begin{tabular}{|c|c|c|c|c|c|c|}
\hline & \multicolumn{4}{|c|}{$\begin{array}{l}\text { Evet ise aldığınız girişimcilik dersinin/eğitiminin sizi girişimciliğe } \\
\text { yönlendirdiğini düşünüyor musunuz? }\end{array}$} & \multirow{3}{*}{$\mathbf{t}$} & \multirow{3}{*}{$\mathrm{p}$} \\
\hline & \multicolumn{2}{|c|}{ Evet } & \multicolumn{2}{|c|}{ Hayır } & & \\
\hline & Ort & ss & Ort & ss & & \\
\hline $\begin{array}{l}\text { Davranışa Yönelik Tu- } \\
\text { tum }\end{array}$ & 4,05 & ,76 & 3,32 & 84 & 3,077 &, $003^{*}$ \\
\hline $\begin{array}{l}\text { Varsayılan Davranış } \\
\text { Kontrolü }\end{array}$ & 4,13 & 71 & 3,88 & 63 & 1,183 & 242 \\
\hline Kişisel Norm & 3,81 & ,71 & 3,44 & ,85 & 1,637 & 107 \\
\hline Dışadönüklük & 3,67 & 43 & 3,46 & 48 & 1,555 & 125 \\
\hline Nevrotiklik & 3,02 &, 58 & 3,08 & ,36 & $-0,368$ & ,714 \\
\hline Sorumluluk & 3,43 & 44 & 3,48 & ,38 & $-0,440$ & ,662 \\
\hline Uyumluluk & 3,35 & 41 & 3,25 & 38 & 0,803 & 426 \\
\hline Deneyime Açıklık & 3,85 & 47 & 3,64 &, 35 & 1,588 & ,118 \\
\hline
\end{tabular}

${ }^{*} p<0,05$ Bağımsiz gruplar t testi

Alınan girişimcilik dersi/eğitiminin kendisini girişimciliğe yönlendirdiğini düşünme durumu farklı olan gruplar arasında Davranışa Yönelik Tutum açısından istatistiksel olarak anlamlı farklılık bulunmaktadır 
$(p<0,05)$. Buna göre almış oluğu girişimcilik dersi/eğitiminin kendisini girişimciliğe yönlendirdiğini düşünenlerin puan ortalaması daha yüksektir.

Alınan girişimcilik dersi/eğitiminin kendisini girişimciliğe yönlendirdiğini düşünme durumu farklı olan gruplar arasında girişimcilik eğilimleri açısından istatistiksel olarak anlamlı farklılık bulunmamaktadır $(\mathrm{p}>0,05)$.

\section{Tartışma}

Araştırma sonuçlarına göre girişimcilik eğitimi almış öğrencilerin girişim eğilimlerinin arttığı söylenebilir. Bu sonuç daha önce yapılmış çalışmaları destekler niteliktedir. Kaplan (2020)' nın yapmış olduğu çalışmada özerkliğe, yönetimsel yetkinliğe, girişimciliğe ve rekabete önem veren üniversite öğrencilerinin ortak olarak dışadönük ve deneyime açık bireyler oldukları ancak sorumluluk ve uyumluluk özelliklerinin düşük oranda olduğu görülmüştür. Bu sonuçlar Şentürk ve Buran (2015)'ın, Batur ve Ad1güzel (2014)'in çalışmalarıyla desteklenmektedir. Aksel ve Bağcı (2016) bireylerde girişimcilik eğilimini artırmak ve girişimci kişilik oluşturmak için girişimcilik eğitimine küçük yaşlardan başlanması, yükseköğrenimde ise girişimcilik derslerinin uygulamalı verilmesi üzerinde durmuştur. Uygun ve Güner (2016), yaptıkları araştırmalar ile girişimcilik eğitiminin gelecekte başarılı bir girişimci olma şansını artırdı ğı, girişimciliğe yönelik anlayış ve farkındalığı geliştirerek bilgi düzeyini yükselttiği, olumlu tutum ve eğilimi teşvik ettiğini saptamışlardır.

Analiz sonuçlarına göre, kişilik olarak Deneyime Açıklık özelliğine sahip olmanın, öğrencilerin girişimcilik eğilimini pozitif etkilediği anlaşılmıştır. Bu sonuç literatürde yapılmış olan çalışmaları desteklemektedir. Literatür incelendiğinde Bozkurt ve Erdurur (2013), Kazaferoğlu (2017), Konaklığlu ve Kızanlıklı (2011)' nın üniversite öğrencilerinin kişilik özelliklerinin girişimcilik eğilimi üzerine etkisini araştırdığı görülmektedir. Araştırma sonucunda kişilik özelliklerinin girişimcilik eğilimi üzerinde etkisinin olduğu sonucuna varılmıştır. Özdevecioğlu ve Karaca (2015), kişiliğin ve kişilik özelliklerinin girişimcilik üzerindeki etkisini incelemiş, Türkiye' de faaliyet gösteren girişimciler üzerinde yapılan araştırma sonucunda kişilik özelliklerinin girişimciliği etkilediğini ortaya koymuştur. 
Verilerin analizi sonucu demografik faktörlerin ve öğrencilerin kişilik özelliklerinin öğrencilerin girişimcilik niyetlerini etkilediği belirlenmiştir. Şeşen ve Basım (2012) ve Salik ve Kaygın (2016)' nın yapmış olduğu çalışmalarda da aynı yönde sonuçlara ulaşılmıştır. İrmiş ve Barutçu, (2012), üniversite öğrencilerinin girişimcilik dersi alanların ve ailede bir girişimci rol modeli olanların girişimci kişilik özelliklerinin daha yüksek olduğu tespit edilmiştir. Bu çalışma da aynı sonuca ulaşmıştır.

Çalışmanın sonuçlarına göre girişimcilik eğiliminin cinsiyete göre bir farklılık sergilemediği sonucuna varılmıştır. Bu sonuç literatürdeki bazı çalışmaları destekler niteliktedir. Yılmaz ve Sünbül (2009), girişimcilik düzeylerinde cinsiyete göre anlamlı farklılık bulmamıştır. Yılmaz ve Günel (2011), öğrencilerin kendi işini kurma isteği ile cinsiyet, üniversite eğitimi almış olmak arasında bir ilişki olmadığı, ebeveynlerin çalışma alanları arasinda bir ilişki olduğunu tespit etmiştir. Kayalar ve Ömürbek (2007) ise cinsiyetin risk alma üzerinde anlamlı bir fark yaratmadığını tespit etmiştir.

\section{Sonuç ve Değerlendirme}

Girişimcilik kişisel, ekonomik ve toplumsal değer yaratmaktadır. Birey açısından daha fazla kazanç sağlamak, kendi işini yaptığı için özgür olmak, özgüven ve statüyü arttırmak gibi olumlu yönleri bulunmaktadır. Ülke ekonomisini güçlendirdiği ve ülke kalkınmasında yarar sağlandığı söylenebilir. Bunların yanı sıra girişimcilik üretim ve bilişim teknolojilerinin hızla değişmesi, kaynak ve sermaye gerektirmesi, ekonomik- politik çevrede etkilenmesi sebebiyle risk almayı gerektirmekte ve içinde başarısızlık olasılığı barındırmaktadır. Bu nedenle riskleri en aza indirmek, bireylerde girişimcilik eğilimini artırmak ve girişimci kişilik oluşturmak gerekmektedir.

Bu amaçla üniversite öğrencilerinin kişilik tipleri ile girişimcilik eğilimleri arasındaki ilişkide demografik özelliklerin etkisi araştırılmış ve toplanan verilerin analizi sonucu aşağıdaki bulgulara ulaşılmıştır:

- Kişilik tiplerinden, Deneyime Açıklık ve Dışa dönüklük girişimcilik eğilimini pozitif etkilemektedir. Deneyime ve yeniliğe açık öğrencilerin girişimcilik eğiliminin diğer kişilik tiplerine göre daha 
yüksek olduğu söylenebilir. Nevrotiklik, sorumluluk ve uyumluluk kişilik tiplerine sahip öğrencilerin girişimcilik eğilimleri zayıf bulunmuştur

- Kadın ile erkekler arasında kişilik tipleri ve girişimcilik eğilimleri açısından istatistiksel olarak anlamlı farklılık bulunmamıştır.

- Yaşı farklı olan gruplar arasında kişilik tipleri ve girişimcilik eğilimleri açısından istatistiksel olarak anlamlı farklılık ortaya çıkmamiştır.

- Sınıfı farklı olan gruplar arasında kişilik tiplerinden Uyumluluk açısından istatistiksel olarak anlamlı farklılık tanımlanmamıştır. Buna göre 2.sınıf olanların puan ortalaması en yüksek iken, 1.sınıf olanların ortalaması en düşük belirlenmiştir.

- Annesi okuryazar olanların puan ortalaması en yüksek iken, ilkokul mezunu, üniversite mezunu olanların ortalaması en düşük görülmektedir. Annesi okuryazar olanların diğerlerine göre girişimcilik eğiliminin daha fazla olduğu söylenebilir.

- Davranışa Yönelik Tutum açısından ve Varsayılan Davranış Kontrolü açısından babası okuryazar olanların oranı en yüksek iken, ilkokul mezunu olanların oranı en düşüktür. Babası ortaokul ya da üniversite mezunu olanların oranı en yüksek iken ilkokul mezunu olanların oranı en düşüktür.

- Kişilik Tipleri ile Girişimcilik Eğilimleri açısından yapılan analizde öğrencilerin ailesinde girişimci olanların oranının daha yüksek olduğu görülmektedir.

- Girişimcilik eğilimleri açısından öğrencilerin kendi işini yapmak idealinde oldukları ifade edilebilir.

- Kişilik Tiplerinden biri olan Nevrotiklik kişiliğine sahip olanların, kendi işini yapma idealine sahip olduğu ve özel sektörde çalışmak idealine daha az sahip olduğu tespit edilmiştir.

- Girişimcilik eğitimi almış öğrencilerin girişim eğilimlerinin arttığ1 görülmektedir.

- Alınan girişimcilik dersi/eğitiminin öğrencileri girişimciliği düşünmeye yönlendirdiği tespit edilmiştir.

Araştırma sonuçları değerlendirildiğinde öğrencilerin girişimcilik eğilimin destekleyecek bazı önerilerde bulunmak mümkündür. Kişilik tiplerinden, deneyime açık ve dışa dönük öğrencilerin girişimcilik eğilimleri 
desteklenerek, inovatif girişim hayallerini ortaya çıkarmalarına olanak sağlanabilir.

Girişimcilik eğitimi ile öğrencilerin yaratıcılık ruhunu, risk alma ve bağımsızlık gibi özelliklerini güçlendirmek mümkün olacaktır. Ayrıca motivasyon oluşturularak girişimcilik yolunda ilerlemelerine de olanak sağlanacaktır. Girişimcilik programları kapsamında, işletme yönetimi ile ilgili temel beceriler, yasal prosedürler, hukuki işlemler, personel seçimi ve özellikleri, pazarlama çalışmaları, halkla ilişkiler çalışmaları vb. konularda eğitim verilebilmektedir. Bu bağlamda geleceği girişimcileri olan üniversite öğrencilerinin gerekli riskleri alarak elde bulundurdukları kaynakları en iyi şekilde kullanmaları mümkün olacaktır. Bu eğitimler sonucunda, öğrenciler girişim kararı vermeden önce konuyla ilgili bilgi sahibi olacak ve böylece yapacakları girişimin başarı şansı artacaktır.

Üniversitelerde bölüm derslerinin yanı sıra uygulamalı olarak girişimcilik derslerine de yer verilebilir. Girişimcilik ile ilgili seminer, konferans ve paneller düzenlenerek, öğrencilerin katılımı teşvik edilebilir. Bu toplantılara davet edilen başarılı girişimcilerin, başarı hikayelerini öğrencilerle paylaşılmasının girişimcilik eğilimine artmasına katkıda bulunacağını söyleyebiliriz. Girişimcilik programları açılarak, girişimcilik geliştirilebilir ve özendirilebilir. Sanayi işbirlikleri yapılmasının yanı sıra, üniversite teşviki ile akademisyenlerin şirketler kurması, onların girişimci yönlerini öğrencilere gösterme fırsatı bulmalarını sağlayacaktır. Üniversitelerin bünyesinde kurulan kuluçka merkezleri yoluyla girişim yapma fırsatı verilerek fark yaratan yeni fikirler desteklenebilir. 


\title{
EXTENDED ABSTRACT
}

\section{Examining the Relationship between University Students' Personality Types and Entrepreneurial Tendencies in Terms of Demographic Characteris- tics: An Example of a Foundation University}

\author{
Vildan Bayram - Mesut Öztırak \\ İstanbul Aydın Univesity-İstanbul Esenyurt University
}

Entrepreneurship has become a motor power that takes the economy forward in Turkey and in the world. In the globalizing world, due to the rapidly changing economic conditions, it is expected that new initiatives will be made and new entrepreneurs will be raised. Entrepreneurship is a great power that forms the economic basis of countries in every period. Directing this power correctly and ensuring the sustainability of enterprises by institutionalizing them is one of the necessary elements for the regular functioning of economic dynamics.

The fact that the entrepreneurial tendencies of employees with different personality types change depending on their personalities is actually important in terms of supporting entrepreneurship. People with entrepreneurial prone personalities can develop a tendency to make entrepreneurial decisions if they are supported. In the long run, this will ensure the development and growth of the country's economy, and the emergence of new service and production areas. In this context, increasing the entrepreneurial tendency in individuals and creating an entrepreneurial personality will also minimize the risks of those who will attempt.

In this study, the effect of demographic characteristics and entrepreneurship education on the relationship between personality types and entrepreneurial tendencies of university students, who are the entrepreneurs of the future, was investigated. The main purpose of this research is to investigate the effect of demographic characteristics on the relationship between personality types and entrepreneurial tendencies of university students in Turkey. For this purpose, students' personality traits and entrepreneurship tendencies were examined, and the effects of demographic 
characteristics on entrepreneurial tendencies were investigated. The necessary ethics committee approval, dated 20.05.2021 and numbered 2021/06-09, was obtained from Istanbul Esenyurt University regarding the study. For this purpose, 196 students studying at a foundation university were reached by using the convenience sampling method. The collected data were analyzed with the SPSS 21.0 program. Independent groups $t$ test, ANOVA test, Tukey test and Pearson correlation test were used in the analyses. Personality traits were examined under five factors. The study contains some limitations. The date the data were collected coincided with the period of the Covid 19 outbreak. During this period, university students are studying online. Epidemic psychology and the lack of face-to-face education may not have allowed students to evaluate freely while answering the survey questions. In addition, data were collected only from students studying at a foundation university. Therefore, the results cannot be generalized. Studies with a larger sample group will provide the opportunity to reach healthier results. In future studies, it can be compared how the entrepreneurship course given at state universities and foundation universities affects the entrepreneurship tendency of students.

According to the results of this study, it was seen that Openness to Experience and Extraversion of Personality types affect the entrepreneurial tendency positively, the entrepreneurship tendency of students who are open to experience and innovation is higher than other personality types, and the entrepreneurial tendencies of students with neuroticism, responsibility and adaptability personality types are weak. There was no statistically significant difference between men and women in terms of personality types and entrepreneurial tendencies. There was no statistically significant difference between the age groups in terms of personality types and entrepreneurial tendencies. There was no statistically significant difference between the groups with different classes in terms of compatibility from personality types. Accordingly, while the average score of the 2nd class students was the highest, the average of the 1st class students was the lowest. While the average score of those whose mothers are literate is the highest, the average of those who are primary school graduates and university graduates is the lowest. It can be said that those whose mothers are literate have a higher tendency to entrepreneurship than others. In terms of Attitude Towards Behavior and Default Behavior Control, the 
rate of literate fathers is the highest, while the rate of primary school graduates is the lowest. While the rate of those whose fathers are secondary or university graduates is the highest, the rate of primary school graduates is the lowest. In the analysis made in terms of Personality Types and Entrepreneurship Tendencies, it is seen that the rate of entrepreneurs in the families of the students is higher. In terms of entrepreneurial tendencies, it can be stated that students have the ideal of doing their own business. It has been determined that those who have the neuroticism personality, which is one of the Personality Types, have the ideal of doing their own work and less ideal of working in the private sector. It is seen that the entrepreneurship tendencies of students who have received entrepreneurship education have increased. It has been determined that the entrepreneurship course/training taken directs the students to think about entrepreneurship. When the results of the research are evaluated, it is possible to make some suggestions to support the entrepreneurial tendency of the students. Entrepreneurial tendencies of students who are open to experience and extrovert can be supported to reveal their innovative entrepreneurial dreams.

With entrepreneurship education, it will be possible to strengthen students' spirit of creativity, risk taking and independence. In addition, motivation will be created and it will be possible for them to progress on the path of entrepreneurship. Within the scope of entrepreneurship programs, basic skills related to business management, legal procedures, legal transactions, personnel selection and characteristics, marketing studies, public relations studies, etc. subjects can be trained. In this context, it will be possible for university students, who are entrepreneurs of the future, to take the necessary risks and use the resources they have in the best way. As a result of these trainings, students will have information about the subject before making a decision about the venture, and thus the chances of success of their venture will increase.

In addition to department courses, applied entrepreneurship courses can also be included in universities. Participation of students can be encouraged by organizing seminars, conferences and panels on entrepreneurship. We can say that sharing the success stories of the successful entrepreneurs invited to these meetings with the students will contribute to the increase in the entrepreneurship tendency. Entrepreneurship can be 
developed and encouraged by opening entrepreneurship programs. In addition to making industry collaborations, the establishment of companies by academicians with university incentives will enable them to have the opportunity to show their entrepreneurial aspects to students. New ideas that make a difference can be supported by giving the opportunity to venture through incubation centers established within universities.

In line with these results, we can say that the hypotheses of the research are supported by the data obtained. The hypotheses that personality types differ significantly according to demographic variables, entrepreneurial tendency differs significantly according to demographic variables, and personality types support entrepreneurial tendency are supported by acceptable values. Accordingly, it was determined that demographic factors and students' personality traits affect students' entrepreneurial intentions. As a result of the analysis of the data, it was determined that the demographic factors and the personality traits of the students affected the entrepreneurial intentions of the students. Entrepreneurial tendencies of students whose personality types are open to experience and extrovert are supported, and their dreams of innovative entrepreneurship are revealed.

\section{Kaynakça/References}

Ajzen, I. ve Fishbein, M. (1977). Attitude-behavior relations: A theoretical analysis and review of empirical research. Psychological bulletin, 84(5), 888.

Akçakanat, T., Çarıkçı, İ. H., ve Mücevher, M. H. (2014). Sözel, sayısal ve eşit ağırlık bölümlerinde okuyan üniversite öğrencilerinin girişimcilik eğilimlerinin bazı demografik değişkenler açısından incelenmesi: SDÜ örneği. AKÜ İ̈BF Dergisi, 16(2), 137-153.

Akkuş, Y., Akdoğan, Ç. ve Akyol, A. (2018). Kişilik özellikleri ve girişimci kişilik boyutlarının girişimcilik niyeti üzerindeki etkileri: Trakya örneği. Electronic Journal of Vocational Colleges, November, 171-174.

Aksel, İ. ve Bağcl, Z. (2016). Girişimcilik eğilimi; Bir kamu üniversitesinin İiB'sinde öğrenim gören son sinıf öğrencilerinde bir araştırma. İnsan ve Toplum Bilimleri Araştrmaları Dergisi, 5(7), 2120-2133.

Akyüz, Y. (2013). Üniversite öğrencilerinin Kosgeb desteklerine bakış açıları ve girişimcilik eğilimleri üzerine bir araştırma: Uşak Üniversitesi örneği. Uşak Üniversitesi Sosyal Bilimler Dergisi, 6(3), 81. 
Alan, H. ve Korkmaz, F. (2017). Sosyal ağ ilişkilerinde çok yönlü bağlar ve kişilik arasındaki ilişkiler: Hastane yöneticileri üzerine bir araştırma. Pesa Uluslararası Sosyal Araştırmalar Dergisi, 3(4), 104-118.

Allport, G. W. (1961). Pattern and growth in personality. New York: Holt, Rinehart and Winston, Inc.

Atasoy, T. (2012). Kendinizin patronu olmak: Girişimcilik. Ankara: ODTÜ Yayıncllı.

Bacanlı, H., İlhan, T. ve Aslan, S. (2009). Beş faktör kuramına dayalı bir kişilik ölçeğinin geliştirilmesi: Sıfatlara dayalı kişilik testi (SDKT). Türk Ĕ̆itim Bilimleri Dergisi, 7(2), 261-279.

Bal, F. (2018). Engelli çocuğa sahip bireylerin kişilik özelliklerinin depresyon ve stres üzerindeki etkisinin incelenmesi. The Journal of Academic Social Science, 79, 71-90.

Baltacı, A. (2017). Erteleme davranışı eğilimi ve beş faktör kişilik özellikleri arasındaki ilişkiler: Okul yöneticileri üzerine bir araştırma. International Journal of Contemporary Educational Studies, 3(1), 56-80.

Barutçu, E. ve İrmiş, A. (2012). Öğrencilerin kendilerini girişimci bir kişiliğe sahip görmelerini ve iş kurma niyetlerini etkileyen faktörler: Bir alan araştırmas1. Atatürk Üniversitesi İktisadi ve İdari Bilimler Dergisi, 26(2), 1-25.

Basım, H. N., Çetin, F. ve Tabak, A. (2009). Beş faktör kişilik özelliklerinin kişilerarası çatışma çözme yaklaşımlarıyla ilişkisi. Türk Psikoloji Dergisi, 24(63), 20-34.

Batur, H. Z. ve Adıgüzel, O. (2014). Schein'in kariyer değerleri perspektifinde öğrencilerin kariyer tercihlerini etkileyen faktörler üzerine bir araştırma: Isparta ili fen lisesi öğrencileri örneği. Dumlupınar Üniversitesi Sosyal Bilimler Dergisi, 42, 327-348.

Bridge, S., ve O'Neill, K. (2012). Understanding enterprise: Entrepreneurship and small business. Palgrave Macmillan.

Bozkurt, Ö., Ercan, A., Yurt İ, (2018). Bireysel değerler ile girişimcilik eğilimi arasındaki ilişkinin değerlendirilmesi: Düzce Üniversitesi örneği. Girişimcilik ve Kalkınma Dergisi, 13(1), 43-55.

Bozkurt, Ö. ve Erdurur, K. (2013). Girişimci kişilik özelliklerinin girişimcilik eğilimindeki etkisi: Potansiyel girişimciler üzerinde bir araştırma. Girişimcilik ve Kalknma Dergisi, 8(2), 57-78.

Burger, J. M. (2006). Kişilik. İstanbul: Kaknüs Yayınları.

Çetin, F., Yeloğlu, H. O. ve Basım, H. N. (2015). Psikolojik dayanıklılığın açıklanmasında beş faktör kişilik özelliklerinin rolü: Bir kanonik ilişki analizi. Türk Psikoloji Dergisi, 30(75), 81-92. 
Çivitci, N. ve Arıcıŏlu, A. (2012). Beş faktör kişilik kuramına dayalı kişilik özellikleri. Mehmet Akif Ersoy Üniversitesi Eğitim Fakültesi Dergisi, 23, 78- 96.

Dal, V. ve Eroğlu, A. H. (2015). Farklı kişilik özelliklerine sahip bireylerin risk algılarının tüketici davranışı açısından incelenmesi: Üniversite öğrencileri üzerine bir araştırma. Süleyman Demirel Üniversitesi İktisadi ve İdari Bilimler Fakültesi Dergisi, 20(2), 361-385.

Davidsson, P. (1995). Determinants of Entrepreneurial Intentions, Jönköping International Business School (JIBS) S-551 11 Jönköping SWEDEN, RENT IX Workshop, Piacenza, Italy.

DeCarlo, L. T. (1997). On the meaning and use of kurtosis. Psychological methods, 2(3), 292.

Demirci, M. K., Özler, D. E. ve Girgin, B. (2007). Beş faktör kişilik modelinin işyerinde duygusal tacize (mobbing) etkileri-hastane işletmelerinde bir uygulama. Journal of Azerbaijani Studies, 10(3-4) 13-39.

Deniz, A. ve Erciş, A. (2010). Kişilik özellikleri, hedonik ve rasyonel fayda, marka duygusu ve marka bağlllı̆̆ arasındaki ilişkilerin belirlenmesine yönelik bir araştırma. Atatürk Üniversitesi İktisadi ve İdari Bilimler Dergisi, 24(2), 141- 165.

Divanoğlu, S. U. ve Uslu, T. (2018). Kişilik özelliklerinin oluşumunda astrolojinin önemi. Journal of Social and Humanities Sciences Research, 5(30), 4340- 4356.

Ercan, S. ve Gökdeniz, İ. (2009). Girişimciliğin gelişim süreci ve girişimcilik açısından Kazakistan. Bilig Türk Dünyası Sosyal Bilimler Dergisi, 49, 59-82.

Eren, E. (2008). Örgütsel davranış ve yönetim psikolojisi (11.Baskı). İstanbul: Beta Yayınevi.

Erkuş, A. ve Tabak, A. (2009). Beş faktör kişilik özelliklerinin çalışanların çatışma yönetim tarzlarına etkisi: Savunma sanayinde bir araştırma. Atatürk Üniversitesi İktisadi ve İdari Bilimler Dergisi, 23(2), 213- 242.

Erten, S. (2002). Kız ve erkek öğrencilerin evde enerji tasarrufu yapma davranış amaçlarının planlanmış davranış teorisi yardımıyla araştııılması. Hacettepe Üniversitesi, Edebiyat Fakültesi Dergisi, 22, 67-73.

Fritz, M. S. ve MacKinnon, D. P. (2007). Required sample size to detect the mediated effect. Psychological science, 18(3), 233-239.

Gast, J. ve Gundolf, K. (2017). Doing business in a green way: A systematic review of the ecological sustainability entrepreneurship literature and future research directions. Journal of Cleaner Production, 147(2017), 46.

George, J. M. and Jones, G. R. (2012). Understanding and managing organizational behavior. (6th Edition). New Jersey: Prentice Hall. 
Goldberg, L. R. (1990). An alternative description of personality: The big-five factor structure. Journal of Personality and Social Psychology, 59(6), 1216- 1229.

Groeneveld, R. A. ve Meeden, G. (1984). Measuring skewness and kurtosis. Journal of the Royal Statistical Society: Series D (The Statistician), 33(4), 391-399.

Guenole, N. and Chernysenko, O. S. (2005). The suitability of Goldberg's big five rpip personality markers in New Zealand: A dimensionality, bias and criterion validity evaluation. New Zealand Journal of Psychology, 34(2), 86-96.

Güney, S (2017). Örgütsel davranış. İstanbul: Nobel Yayınevi.

Hayes, J. (2018). The theory and practice of change management. UK: Macmillan Education.

Hayes, A. F. ve Rockwood, N. J. (2017). Regression-based statistical mediation and moderation analysis in clinical research: Observations, recommendations, and implementation. Behaviour research and therapy, 98, 39-57.

Horzum, M. B., Ayas, T. ve Padır, M. A. (2017). Beş faktör kişilik ölçeğinin Türk kültürüne uyarlanması. Sakarya University Journal of Education, 7(2), 398408.

Hopkins, K. D. ve Weeks, D. L. (1990). Tests for normality and measures of skewness and kurtosis: Their place in research reporting. Educational and Psychological Measurement, 50(4), 717-729.

İyem, C. ve Erol, E. (2013). Mesleki yönelimlerde bireylerin kişilik ve demografik özelliklerinin rolü; Sakarya Üniversitesi İşletme Bölümü örneği. Sosyal ve Beşeri Bilimler Dergisi, 5(1), 137-146.

John, O. P., Donahue, E. M. ve Kentle, R. L. (1991). Big five inventory. Journal of Personality and Social Psychology, 31(2), 558-595.

Kaplan, N. (2020). Kişilik özelliklerinin kariyer değerleri üzerindeki etkisi: Üniversite öğrencileri üzerine bir araştırma. Güncel Pazarlama Yaklaşımları ve Araştırmaları Dergisi, 1(2), 132-152.

Karabatak, S. (2019). Okul yöneticilerinin beş faktör kişilik özellikleri ile yönetsel güçlülükleri arasındaki ilişki. Hacettepe Üniversitesi Eğitim Fakültesi Dergisi, 5(1), 1-17.

Kayalar, M. ve Ömürbek, N. (2007). Girişimci adaylarinin risk almaya yatkinlik özelliğinin cinsiyet bağlaminda incelenmesi. Atatürk Üniversitesi İktisadi ve İdari Bilimler Dergisi, 21(1), 185-200.

Kazaferoğlu, E. (2017). Kişilik özellikleri ile girişimcilik eğilimi ilişkisi: Süleyman Demirel Üniversitesi öğrencileri üzerine bir araştırma. Yayımlanmış Yüksek Lisans Tezi. Süleyman Demirel Üniversitesi, Sosyal Bilimler Enstitüsü, Isparta. 
Keleş, Y. ve Keleş, M. Ç. (2017). Turizm öğrencilerinin kişilik özellikleri: Türkiye'de lisans düzeyinde turizm eğitimine yönelik bir değerlendirme. The Journal of Academic Social Science Studies, 62, 417-428.

Kılıç, R. ve Bozkaya, E. (2014). Örgüt çalışanlarının kişilik özellikleri ile örgütsel bağlılıkları arasındaki ilişkinin incelenmesi. Süleyman Demirel Üniversitesi Sosyal Bilimler Enstitüiü Dergisi, 20, 153-178.

Kılıçlar, A., Şahin, A. Sarıkaya, G. S., ve Bozkurt, İ. (2017). Kişilik tiplerinin tat tercihine etkisi. Journal of Tourism and Gastronomy Studies, 5(3), 93-117.

Kılınç, E., ve Kanayıran, B. (2020). İşletme fakültesi öğrencilerinin psikolojik sermaye düzeylerinin girişimcilik eğilimleri üzerindeki etkisinin incelenmesi. International Journal of Management and Administration, 4(7), 34-53.

Kızanlıklı, M. ve Konaklığlu, E. (2016). Üniversite öğrencilerinin kontrol odağı ve kariyer tercihlerinin zaman yönelimleri üzerindeki rolü. Gazi Üniversitesi İktisadi ve İdari Bilimler Fakültesi Dergisi, 18(1), 172-191.

Konakay, G. ve Çelik, F. (2018). Kişilik kuramları ve psikolojik sözleşme etkileşiminin işletmelere yansıması. Journal of Human Sciences, 15(2), 697- 706.

Leroy, H., Maes, J., Sels, L., Debrulle, J. ve Meuleman, M. (2009). Gender effects on entrepreneurial intentions: A Tab Multi Group Analysis at factor and indicator level. Paper presented at the Academy of Management Annual Meeting. 7-11 August 2009. Chicago (USA).

Madran, C. ve Akdoğan, T. (2010). Satıcıların kişilikleri ile performanslarının ilişkisi: Beş faktör modeline göre bir analiz. Çukurova Üniversitesi Sosyal Bilimler Enstitüsü Dergisi, 19(1), 366-381.

Moors, J. J. A. (1986). The meaning of kurtosis: Darlington reexamined. The American Statistician, 40(4), 283-284.

Nunnally, J. C. (1967). Psychometic Theory. New York: McGraw-Hill, Inc.

Özdamar, K. (2003). Modern bilimsel araştırma yöntemleri. Eskişehir: Kaan Kitabevi, 116-118.

Özdevecioğlu, M. ve Karaca, M. (2015). Girişimcilik girişimci kişilik kavram ve uygulama. Şehir: Eğitim Yayınevi.

Özbey, Ö. D, Gelmez, E. ve Ergün, Z. (2016). An application for determining entrepreneurial Tendencies: The case of Selcuk University. 1st International Academic Research Congress, Konya.

Öztırak, M. (2017). Kurumsal eğitim veren eğitmenlerde girişimci kişilik ile işkoliklik ilişkisi. (Yayımlanmamış Yüksek Lisans Tezi). İstanbul Aydın Üniversitesi Sosyal Bilimler Enstitüsü. İstanbul. 
Polatcı, S. ve Yeloğlu, H. O. (2021). Karanlık ve aydınlık kişilik özelliklerinin girişimcilik niyeti üzerindeki etkisinin incelenmesi. Journal of Organizational Behavior Review, 3(1), 73-87.

Polatçı, S., Irk, E., Gültekin, Z. ve Sobacı, F. (2017). Psikolojik dayanıklılık ve kişilik özellikleri tatmin düzeyini etkiler mi? Süleyman Demirel Üniversitesi Sosyal Bilimler Enstitüsü Dergisi, 29, 553-578.

Preacher, K. J. ve Selig, J. P. (2012). Advantages of Monte Carlo confidence intervals for indirect effects. Communication Methods and Measures, 6(2), 77-98.

Richards, J. C. and Schmidt, R. (2002). Longman dictionary of language teaching\& applied linguistics. (3rd Edition). London: Pearson Education.

Riemann, R., Angleither, A. and Strelau, J. (1997). Genetic and environmental influences on personality: A study of twins reared together using the selfand peer report NEO-FFI scales. Journal of Personality, 65(3), 449-475.

Runyan, R., Droge, C. ve Swinney, J. (2008). Entrepreneurial orientation versus small business orientation: What are their relationships to firm performance? Journal of Small Business Management, 46(4), 567-588.

Salik, N. ve Kaygın, E. (2016). Demografik değişkenler açısından üniversite öğrencilerinin girişimcilik eğilimlerinin belirlenmesi: Kafkas Üniversitesi örneği. Kahramanmaraş Sütçü İmam Üniversitesi Sosyal Bilimler Dergisi, 13(1), 146.

Sümer, N., Lajunen, T. ve Özkan, T. (2005). Big five personality traits as the distal predictors of road accident. Traffic and transport psychology: Theory and application, 215, 215-227.

Şentürk, E. E. ve Buran, K. (2015). Ön lisans öğrencilerinin kariyer değerlerini etkileyen faktörler üzerine bir araştırma. Electronic Journal of Vocational Colleges-Kasim, 14, 162-180.

Şeşen, H. ve Basım, H. N. (2012). Demografik faktörler ve kişiliğin girişimcilik niyetine etkisi: Spor bilimleri alanında öğrenim gören üniversite öğrencileri üzerine bir araştırma. Ege Akademik Bakış, 12, 21-28.

Şimşek, Ş. ve Çelik, A. (2015). İşletme Bilimlerine Giriş (22. baskı). Ankara: Eğitim Kitabevi.

Taggar, S., Hackett, R. and Saha, S. (1999). Leadership emergence in autonomous work teams: antecedents and outcomes. Personel Psychology, 52, 899-926.

Tatlılıŏlu, K. (2014). Üniversite öğrencilerinin beş faktör kişilik kuramına göre kişilik özellikleri alt boyutlarının bazı değişkenlere göre incelenmesi. Tarih Okulu Dergisi, 17, 939-971. 
Tokmak, M. (2018). Kişilik özelliklerinin örgütsel sessizlik üzerindeki etkisine yönelik bir araştırma: Banka çalışanları örneği. Hitit Üniversitesi Sosyal Bilimler Enstitüsü Dergisi, 3, 2219-2233.

Top, S. (2006). Girişimcilik Keşif Süreci. İstanbul: Beta Basım Yayım.

Tutar, H. ve Yılmazer, A. (2012). Yöneticileri kişilik özelliklerinin pazar odaklılık durumları üzerine etkisi: Sakarya organize sanayi bölgelerinde bir araştırma. Üçüncü Sektör Sosyal Ekonomi, 47(2), 16-29.

Uğur, A. ve Okutan, E. (2018). Kişilik: Tanımı, boyutları, etki faktörleri ve tipolojisi. E. Erdoğan (Ed). Sakarya Üniversitesi çalı̧̧ma ekonomisi ve endüstri ilişkiler seçme yazılar-II içinde (s.1-32). Sakarya: Sakarya Yayınclık.

Ulu, S., Özdevecioğlu, M. ve Ardıç, K. (2016). Kişilik özelliklerinin hasta iken işe gelme (presenteizm) davranışı üzerindeki etkileri: İmalat sanayinde bir araştırma. Erciyes Üniversitesi İktisadi ve İdari Bilimler Fakültesi Dergisi, 47, 167-181.

Ulucan, S. (2015). Girişimcilik Eğiliminin ve Girişimcilik Eğilimini Etkileyen Faktörlerin Analizi: Ortaöğretimde Lise 3. ve 4. Sinnf Öğrencileri Üzerinde Bir Uygulama. Yüksek Lisans Tezi. Gazi Üniversitesi Sosyal Bilimler Enstitüsü, Ankara.

Uygun, M. ve Güner, E. (2016). Girişimcilik eğiliminin gelişiminde girişimcilik eğitiminin rolü. MANAS Sosyal Araştırmalar Dergisi, 5(5), 37-57.

Uysal, D. (2021). Kişilik özelliklerinin girişimcilik eğilimi üzerine etkisi. The International New Issues in Social Sciences, 9(1), 45-70.

Williams, J. ve MacKinnon, D. P. (2008). Resampling and distribution of the product methods for testing indirect effects in complex models. Structural equation modeling: a multidisciplinary journal, 15(1), 23-51.

Yılmaz, B. S. ve Günel, Ö. D. (2011). Üniversite eğitimi ve girişimcilik: Bireyleri girişimciliğe yönlendiren etkenler üzerine bir araştırma. Akademik Bakış Dergisi, 26, 1-20.

Yılmaz, E. ve Sünbül, A. M. (2009). Üniversite öğrencilerine yönelik girişimcilik ölçeğinin geliştirilmesi. Selçuk Üniversitesi Sosyal Bilimler Enstitüsü Dergisi, 21, 195-203.

Zain, Z.M., Akram, A.M. ve Ghani, E.K. (2010). Entrepreneurial intention among Malaysian business students. Canadian Social Science, 6(3), 34-44.

Zhao, H, Seibert, S.E. ve Lumpkin, G.T. (2010). The relationship of personality to entrepreneurial intentions and performance: A meta-analytic review. Journal of Management, 36(2), 381-404. 


\section{Kaynakça Bilgisi/Citation Information}

Bayram, V. ve Öztırak, M. (2021). Üniversite öğrencilerinin kişilik tipleri ile girişimcilik eğilimleri arasındaki ilişkinin demografik özellikler açısından incelenmesi: Bir vakıf üniversitesi örneği. OPUSUluslararası Toplum Araştırmaları Dergisi, 18(44), 8119-8153. DOI:10.26466//opus.944182. 